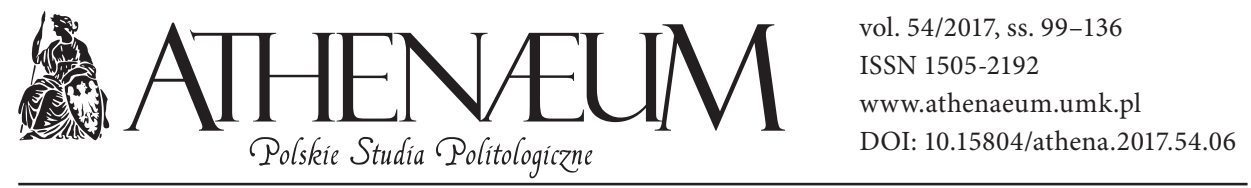

\title{
EWOLUCJA IDEOWO-POLITYCZNA STOWARZYSZENIA PAX W OKRESIE PIERWSZYCH MIESIĘCY „KARNAWAŁU SOLIDARNOŚCI” (SIERPIEŃ-GRUDZIEŃ 1980)
}

\author{
IDEOLOGICAL AND POLITICAL EVOLUTION OF PAX \\ ASSOCIATION DURING THE FIRST MONTHS OF "CARNIVAL \\ OF SOLIDARNOŚĆ" (AUGUST-DECEMBER 1980)
}

\section{Tomasz Sikorski*}

\begin{abstract}
ABSTRAKT
W prezentowanym artykule omówiona została ewolucja ideowo-polityczna Stowarzyszenia PAX w pierwszych miesiącach tzw. „festiwalu Solidarności” (sierpień-grudzień 1980). Przedstawiono podstawowe założenia ideologii i programu ruchu katolików postępowych w okresie, gdy kierował nim nieprzerwanie do zakończenia II wojny światowej Bolesław Piasecki, i ich rewizję po jego śmierci. Skoncentrowano się zwłaszcza na lansowanych przez stowarzyszenie koncepcjach „socjalizmu całego narodu”, samorządności, demokratyzacji, poszerzenia „bazy rządzenia”, wypracowania płaszczyzn do porozumienia narodowego (od Ruchu Porozumienia Narodowego do Wielkiej Koalicji). Analizie poddano również relacje pomiędzy PAX a niezależnymi związkami zawodowymi (NSZZ „Solidarność) oraz aparatem partyjno-rządowym. W programie PAX „Solidarność” nie była typowym związkiem
\end{abstract}

This paper presents political and ideological evolution of PAX Association in the early months of the so-called "Carnival of Solidarność [Solidarity]" (August-December 1980). It concentrates on basic assumptions of ideology and program of progressive Catholics' movement under continuous leadership of Bolesław Piasecki until the end of World War II and on their modifications after his death. It also focuses on the concept of "socialism of the whole nation", promoted by the Association, self-government, democratization, widening of the so-called "government base", and development of common ground for national consensus (from the National Agreement Movement to the Great Coalition). It analyses relationships between PAX Association, independent trade unions (NSZZ "Solidarność") and government apparatus. According to PAX's program, "Solidarność" was not just a typical

* Uniwersytet Szczeciński, Wydział Humanistyczny. 
zawodowym, ale społecznym (ogólnonarodowym) ruchem rewindykacji praw obywatelskich, dlatego przewidywano, że powinien on uczestniczyć jako podmiot w podejmowaniu decyzji państwowych, tworząc nową „oś pionową" struktur państwowych. W okresie „festiwali Solidarności” z niezależnymi związkami zawodowymi związało się wielu członków PAX. Stowarzyszenie włączyło się czynnie w pomoc przy zakładaniu struktur związkowych.

Słowa kluczowe: myśl polityczna, publicystyka polityczna, koncepcje ideowopolityczne, system polityczny, opozycja demokratyczna, ruch katolicki, reżim komunistyczny, związek zawodowy "Solidarność", akcja strajkowa trade union, but a social, nation-wide movement for reclaiming of civil laws. Therefore it was supposed to participate in decision making at government level as an independent being, this creating a new "vertical axis" of state structures. During the period of "Carnival of Solidarność" many PAX members joined independent trade unions. The Association contributed significantly to establishment of trade union structures.

Keywords: political thought, political journalism, ideological and political concepts, political system, democratic opposition, Catholic movement, communist regime, trade union "Solidarity", strike actions

Stowarzyszenie PAX nie doczekało się jak dotąd obszernej monografii, omawiającej jego działalność, myśl polityczną i program. W powszechnej, obiegowej opinii, ale także w pamięci społecznej ciągle postrzegane jest jako serwilistyczna wobec władzy komunistycznej, koncesjonowana organizacja katolików świeckich, która została powołana w celu rozbicia polskiego Kościoła (mit „konia trojańskiego”). Przypomina się jej wezwanie do „puczu” w październiku 1956 roku oraz włączenie w kampanię antysemicką w marcu 1968 r. Sporo kontrowersji budził również lider tego środowiska i jego główny ideolog Bolesław Piasecki, przed wojną związany z Ruchem Narodowo-Radyklanym „Falanga”, któremu zarzucano później działalność agenturalną ${ }^{1}$. Swoisty stereotyp PAX-u, organizacji w pełni podporządkowanej władzy komunistycznej, kształtowany przez wiele lat, powielany w różnych memuarach oraz mniej lub bardziej wartościowych poznawczo artykułach, tworzył obraz organizacji - w swoim programie, obliczu - ideowo politycznym - niezmienny, co dalece rozmija się z prawdą. Stygmat ten, być może niesprawiedliwy i przesadzony trudno było zmienić nawet w latach osiemdziesiątych, kiedy to niektórzy działacze stowarzyszenia (także struktury

1 Materiały dot. uwięzienia Bolesława Piaseckiego zob. IPN Bu 0259/6. Vide szerzej: A. Friszke, A. Paczkowski. (12 IV 2007); (10-17 VI 2007) „Myśl Polska”; A. Jaszczuk (2002, s. 80); J. Engelgard (2008, s. 47-113); A. Micewski (1978, s. 25); A. Paczkowski (2009, s. 79, 82); B. Urbankowski (26 VII 2006); A. Garlicki (1993, s. 22-30); A. Garlicki (1998, s. 82-112); J. Dobraczyński (1977, s. 359-361); A. Friszke (2015, s. 55-79); R. Reiff (2006, s. 49-78); W. Kętrzyński (1967, s. 154-170); N. Pietrow (2013, s. 51-53); R. Niedzielko, B. Noszczak (2006). 
terenowe PAX) wsparli demokratyczną opozycję i niezależne związki zawodowe (NSZZ „Solidarność").

Celem niniejszego artykułu jest analiza ewolucji ideowo - politycznej Stowarzyszenia PAX w pierwszych miesiącach tzw. „festiwalu Solidarności” (sierpień-grudzień 1980 r.). Poruszanemu w artykule zagadnieniu nie poświęcono jak dotąd dokładniejszych badań naukowych, nie licząc prac wspomnieniowych oraz kilku artykułów naukowych, gdzie interesującą nas problematykę jedynie sygnalizowano ${ }^{2}$. Niemniej prezentowany tekst, co należałoby podkreślić, jest tylko przyczynkiem do badań nad działalnością i programem środowiska, który może otworzyć pole do dalszych, pogłębionych studiów w obrębie sygnalizowanej już problematyki.

Stowarzyszenie PAX, skupione pierwotnie wokół tygodnika „Dziś i Jutro”, należało obok ruchu „Znak”, Chrześcijańskiego Stowarzyszenia Społecznego oraz powstałego w 1980 r. Polskiego Związku Katolicko-Społecznego do koncesjonowanego ruchu środowisk katolickich, na stałe wpisanych w system polityczny Polski Ludowej. PAX dysponował własnym „koncernem” prasowym, wydawniczym, szkołą średnią i centralą przemysłowo-handlową ${ }^{3}$ Ścisłe kierownictwo

${ }^{2}$ W dotychczasowej historiografii i badaniach naukowych poświęconych środowisku „Dziś i Jutro” („ruch nienazwany”), z którego wyłoniło się Stowarzyszenie PAX, koncentrowano się na działalności (także strategii i programie politycznym) w pierwszych latach powojennych oraz dekadach: Władysława Gomułki i Edwarda Gierka. Był to okres, kiedy ruchem przez prawie 35 lat kierował Bolesław Piasecki. Jeśli chodzi o późniejszą działalność stowarzyszenia, w badaniach naukowych pojawia się luka. Jest ona szczególnie widoczna, jeśli chodzi o lata 1982-1989. Większość prac poświęconych interesującemu nas środowisku czytelnik odnajdzie w dalszej części artykułu. Nie ma więc potrzeby ich przywoływania w tym miejscu.

3 Stowarzyszenie PAX wydawało pod swoim „szyldem” kilkanaście czasopism, w tym: „Dziś i Jutro” (do 1956 r.), „Słowo Powszechne”, „Kierunki”, „Wrocławski Tygodnik Katolicki”, „Zorzę”, „Tygodnik Powszechny” (w latach 1953-1956), „Życie i Myśl”, „Katolik”, „Głos Katolicki”, „Kultura. Oświata. Nauka: miesięcznik Stowarzyszenia PAX”, „Nowy Nurt: Rzeszów-Białystok-Kielce-Lublin: tygodnik społeczno - kulturalny katolików”, „Nowy Nurt: Wieluń, Sieradz, Wieruszów, Pajęczno: tygodnik społeczno-kulturalny katolików” i inne. W ramach działającego od 1949 r. Instytutu Wydawniczego PAX wydano kilkanaście milionów książek upowszechniających i popularyzujących europejską myśl humanistyczną i religijną, w tym kilka edycji Pisma Świętego. Stowarzyszenie PAX przyznawało również nagrody. Najbardziej prestiżowa była Nagroda Młodych im. Włodzimierza Pietrzaka, przyznawana od 1948 r. za wybitną twórczość naukową, artystyczną, literacką, osiągnięcia w pracy formacyjnej, kulturalno-społecznej i edukacyjnej, będące świadectwem uniwersalnych wartości i postaw ludzkich, chrześcijańskich i patriotycznych. Przyznawana była w kilku kategoriach: naukowej, artystycznej, literackiej, zagranicznej, młodych, zespołowej oraz specjalnej. Od 1949 r. PAX posiadał także prestiżowe Liceum Ogólnokształcące im. Św. Augustyna, od 1992 r. Katolickie Liceum Ogólnokształcące im. Św. Augustyna (już jako Stowarzyszenie Civitas Christiana). W 2004 r. szkoła została zlikwidowana. W 1947 r. PAX otrzymał koncesje na działalność Przedsiębiorstwa Komunikacji 
PAX-u, z jej niekwestionowanym liderem - Bolesławem Piaseckim ${ }^{4}$ wywodziło się z przedwojennego Ruchu Narodowo-Radykalnego „Falanga”, konspiracyjnej Konfederacji Narodu i Batalionów Uderzeniowych. Ze stowarzyszeniem związali się także byli narodowcy, żołnierze konspiracji akowskiej, konserwatyści, a także młoda inteligencja powojenna. Ideowym peregrynacjom nie zawsze przyświecała wspólnota przekonań i zakorzenienie w tradycji. PAX był także „przytuliskiem”, schronieniem przez represjami władz i bezpieki. Miejscem dla politycznego i społecznego zaangażowania. Słowem - realną szansą na obecność w życiu publicznym. Mając do wyboru różne formuły opozycyjności, wybrało zaangażowanie w budowę socjalistycznego państwa wspólnie z marksistami, podkreślając własną odrębność światopoglądową. W pierwszych dokumentach środowiskowych zwracano uwagę, że powojenna rewolucja ma charakter rodzimy, wobec czego nie można przejść obojętnie. Uznając rodzimy charakter „polskiej rewolucji”, zaznaczano, iż oprócz sił materialistycznych (marksistowskich) istnieją także siły spirytualistyczne, dostrzegające potrzebę włączenia się w odbudowę kraju i udział w reformach społeczno-gospodarczych. Środowiska katolickie - stwierdzał Piasecki: „albo się zrewolucjonizują, albo wpływu na rzeczywistość mieć nie będą" (Piasecki, 1945, s. 1). W ruchu paxowskim dominowało przekonanie, że powojenna Polska znalazła się w orbicie wpływów Rosji (unikano jeszcze wówczas formuły - ZSRR) i nie ma żadnej innej alternatywy geopolitycznej wobec powojennego status quo. W Rosji widziano nie tyle „kłopotliwego” sąsiada, ale przede wszystkim sojusznika i gwaranta polskiej suwerenności, rzecznika naszej obecności „nad Odrą i Bałtykiem”. Reprezentowana przez „Dziś i Jutro”, a następnie PAX strategia przystosowania, jak pisał A. Friszke (2003, s. 23), była podyktowana zarówno radykalizmem ideologicznym (Piasecki), jak i realizmem ugodowym w sytuacji braku alternatywy geopolitycznej (Aleksander Bocheński, Jan Meysztowicz). ${ }^{5}$

Samochodowej (działa do 1949 r.), w 1947 r. powstaje spółka „Veritas”, z udziałem Związku Diecezjalnego „Caritas”. W 1949 r. powstaje kolejna spółka firma „Wnętrzne i wystawa” (działa do 1950 r.). Następnie w 1949 PAX zostaje właścicielem Towarzystwa Handlu Międzynarodowego „Inco”, które wraz z Veritasem zostaje w 1953 r. przekształcone w dwie centrale przemysłowo-handlowe. Ostatecznie w 1958 r. powstają tzw. Zjednoczone Zespoły Gospodarcze. PAX dysponował także: amatorskimi zespołami teatralnymi, bibliotekami, klubami dyskusyjnymi, filmowymi i prasowymi.

4 Postać Bolesława Piaseckiego doczekała się już kilku prób biograficznych, np.: J. Engelgard (2015); A. Dudek, G. Pytel (1990); A. Jaszczuk (2002); L. Blit (1965); A. Bromke (1961); M.S. Kunicki (2002), nie uwzględniając dziesiątków artykułów i drobnych studiów.

${ }^{5}$ Wydaje się, że w pierwszym okresie funkcjonowania pisma, tj. w latach 1945-1947, jego profil ideowy oparty był na czterech założeniach głównych: 1) geopolityczny realizm opary na przekona- 
W kwestiach ideowych stowarzyszenie PAX (a wcześniej grupa „Dziś i Jutro”, określająca się do 1948 r. jako „ruch nienazwany”) głosiła swój najważniejszy postulat o potrójnym zaangażowaniu: patriotycznym, socjalistycznym i katolickim, w myśl zasady wieloświatopoglądowości w państwie socjalistycznym (Wójcik, 1978, s. 8-17; Bankowicz, 1989, s. 7-20; Bankowicz, 2009, s. 37-48; Bankowicz, 1996, s. 53-71; Dudek, 2013, s. 69-78; Dudek, 1996, Wiszniewski, 1991, s. 155-156; Sikorski, 2014, s. 75-79; Urbański, 1979). Był on powtarzany w różnych dekadach politycznych, we wszystkich najważniejszych tekstach programowych oraz tzw. „Wytycznych” - najważniejszym dokumencie ideowym (również programowym), uzupełnianym cyklicznie (niemal głównie ręką Piaseckiego), a następnie ogłaszanym w kolejnych zaktualizowanych wersjach.

Bolesław Piasecki - twórca i główny ideolog PAX, po ciężkiej chorobie zmarł w noc sylwestrową 1978/1979, dokładnie w czterdziestą rocznicę śmierci Romana Dmowskiego. Wśród jego potencjalnych następców najczęściej wymieniano: Janusza Stefanowicza, Zygmunta Przetakiewicza, Jerzego Hagmajera i Ryszarda Reiffa ${ }^{6}$. Do czasu ukonstytuowania się nowego zarządu stowarzyszeniem kierował Przetakiewicz 7 . Dwa tygodnie po śmierci Piaseckiego, 14 stycznia 1979 r.,

niu, że ZSRR jest jedynym gwarantem naszej granicy zachodniej, a szerzej suwerenności państwowej i naturalnym sojusznikiem w powstrzymaniu ewentualnej ekspansji Niemiec; 2) rację stanu traktowana jako substytut patriotyzmu; 3) katolicyzm; 4) poparcie dla reform społeczno-ekonomicznych.

${ }^{6}$ Z. Przetakiewicz, R. Reiff i J. Stafanowicz od 1976 r. pełnili funkcję wiceprzewodniczących Stowarzyszenia PAX. W skład Prezydium Zarządu w latach 1976-1980 wchodzili jeszcze: Zbigniew Czajkowski, Jerzy Hagmajer, Marek Kabat, Zenon Komender, Jan Król, Jan Waleczek, Józef Wójcik i Maciej Wrzeszcz.

7 Bolesław Piasecki od dawna ciężko chorował. W październiku 1978 r. został przewieziony do szpitala, na oddział intensywnej terapii z ciężką niewydolnością płuc. Zmarł w noc sylwestrową. Później przez wiele lat krążyły plotki, że być może został otruty, albo sam wyłączył aparaturę medyczną ułatwiającą mu oddychanie. W każdym razie śmierć niekwestionowanego lidera PAX, który przez 35 lat „rządził” stowarzyszeniem, wywołała środowiskowy wstrząs. Por. (7 I 1979) „Kierunki”, nr 1, s. 1; (14 I 1979) „Kierunki”, nr 2, s. 1-2. Cały numer miesięcznika „Życie i Myśl, 4 z kwietnia 1979 r. poświęcono pamięci Piaseckiego. Swoje teksty zamieścili tam m.in.: Jan Dobraczyński, Maria Szyszkowska, Alfons Klafkowski, Jerzy Hagmajer, Mieczysław Kurzyna, Janusz Stefanowicz i Adolf Bocheński. W ciągu pierwszych kilku dni stycznia rozpoczęła się wewnątrzśrodowiskowa dyskusja na temat następcy po B. Piaseckim. Por. J. Wójcik (15-22 I 2017); R. Skwarski (1990, s. 69-75); Z.M. Przetakiewicz jr. (2016, s. 112-115). Należy zaznaczyć, że począwszy od 1971 r. do 1989 r. odbywające się w PAX-ie „wybory” do ciał statutowych były ściśle „monitorowane” przez SB, w ramach Sprawy Obiektowej kryptonim „Alfa”. Z bezpieką współpracowało w tym czasie od kilkunastu do kilkudziesięciu członków najważniejszych organów wewnętrznych Stowarzyszenia PAX, informujących o nastrojach, poglądach ścisłego kierownictwa, opiniach o sytuacji społeczno-politycznej w kraju, 
podczas zebrania zarządu, na nowego przewodniczącego wybrano Reiffa ${ }^{8}$. Przed nowym przewodniczącym stanął ogrom zadań. Należało przede wszystkim uspokoić sytuację w stowarzyszeniu, tym bardziej, że w strukturach terenowych wrzało już od dawna, ale również zająć stanowisko wobec kryzysu politycznego i społeczno-ekonomicznego, z jakim u schyłku lat 70. borykała się ekipa Edwarda Gierka. Niebagatelną sprawą było również zrewidowanie stosunku PAX-u do Kościoła, którego pozycja wówczas ogromnie wzrosła (także w konsekwencji wyboru Karola Wojtyły na Ojca Świętego w 1978 r.). Zarazem na nowym przewodniczącym ciążył obowiązek (nie tyko moralny) kontynuowania dorobku ideowego Piaseckiego, którego polityka wobec Kościoła przyniosła fiasko.

Już na drugim po śmierci Piaseckiego posiedzeniu zarządu PAX (27 II 1979 r.), w obszernym i w wielu miejscach przegadanym referacie programowym Reiff nie szczędził pochwał pod adresem dotychczasowej ideologii i strategii stowarzyszenia, ale jedocześnie namawiał do używania „nowego języka” w relacjach z hierarchią kościelną, wzywał do dialogu i porozumienia. Oczywiście już wcześniej podobne sygnały, czasami intuicyjne, dało się wyczuć w prasie ruchu postępowych katolików, ale nigdy nie brzmiały one tak wyraźnie, a zarazem jednoznacznie. Jeszcze ciekawszy okazał się „wyłom” w głoszonej od początku istnienia stowarzyszenia koncepcji wieloświatopoglądowości, którą Reiff zastąpił postulatem „pluralizmu humanistycznych systemów wartości”. Także pozostałe

udziale w rozlicznych inicjatywach, ale również o życiu prywatnym członków stowarzyszenia. Vide: AIPN 0639/21 t. 1-3.

${ }^{8}$ Ryszard Reiff (ur. 1921) podczas II wojny światowej brał udział w ruchu konspiracyjnym. Był członkiem Konfederacji Narodu, dowódcą jednego z oddziałów Batalionów Uderzeniowych, a po scaleniu z Armią Krajową dowodził kampanią 3. Batalionu 77 Pułku Piechoty AK (ps. Jacek). Uwięziony przez NKWD przebywał na zesłaniu, skąd w 1946 r. powrócił do kraju i związał się ruchem katolików postępowych. Por. R. Reiff, (1993). Zob. też: (21 I 1979) „Kierunki”, nr 3, s. 2; (21 I 1979).W końcu lat czterdziestych Reiff podczas pobytu w Anglii został zwerbowany jako agent polskiego wywiadu i miał się zająć organizacją polskiej siatki wywiadowczej rozpracowującej środowiska emigracyjne w Wielkiej Brytanii. Por. AIPN Bu 00170/286/ t. 1-7. Zob. także: P. Gontarczyk (2006) „Gazeta Polska”, nr 34, s. 22-23; P. Gontarczyk (2006) „Gazeta Polska”, nr 36, s. 14-15. Z zachowanych materiałów wynika, że Reiff włączył się w grę operacyjną z bezpieką, wykorzystując swoją inteligencję oraz umiejętności interpersonalne starał się tak wykonywać nałożone na siebie zadania operacyjne, aby nikomu zaszkodzić. Z.M.jr Przetakiewicz (2016, s. 113-114).W 1980 r. Reiff ponowił współpracę z bezpieką jako TW „Demagog”. Miał się zająć rozpracowywaniem środowisk katolickich, analizą nastrojów w chrześcijańskich organizacjach społecznych i wśród duchowieństwa. Oficerem prowadzącym przewodniczącego PAX był płk. Czesław Wiejak - zastępca dyrektora IV Departamentu MSW, zajmującego się walką z wrogą „antypaństwową” działalnością kościołów, związków wyznaniowych oraz duchownych. Por. AIPN Bu 00170/286/29859/1; Z.M. jr Przetakiewicz, (2016, s. 122-126). 
fragmenty „dyskusji o narodzie” odbiegały od dotychczasowej „ideologicznej klasyki”. Reiff mówił o potrzebie wzięcia przez obywateli odpowiedzialności za losy narodu i państwa, o autentycznej więzi społeczeństwa z narodem, wyraźnie stawiał praktykę społeczną przed ideologią, która wydawała się zawodzić. Jeśli Reiff nie mówił językiem demokratycznej opozycji, to na pewno była to retoryka bliska liberałom partyjnym. Z drugiej jednak strony, jako realiście politycznemu, nie można mu było odmówić zmysłu pragmatycznego. Ale ani na krok nie odstępował od socjalistycznego zaangażowania, uznając kierowniczą rolę partii rządzącej ${ }^{9}$ „Odcedzając” polityczny referat Reiffa, a ściślej rzecz ujmując, polityczne deklaracje od taktyki, jedno nie ulega wątpliwości. Reiff nie zamierzał rewolucjonizować stowarzyszenia, podgrzewać nastrojów, a już na pewno zepchnąć PAX-u na pozycje antysocjalistyczne. Myślał raczej o uspokojeniu nastrojów społecznych, zachowując przy tym aktualny stan posiadania.

Przewodniczący PAX, miał świadomość, że aby PAX nie został zepchnięty na margines życia politycznego, aby nie utracił wpływu na zachodzące w kraju wydarzenia, musi zrewidować przynajmniej część swojej strategii i założeń ideowych i włączyć się w proces „odnowy”, naciskając dyskretnie na władzę. Stowarzyszenie musiało więc w sposób przemyślany i roztropny trochę się „odpiasecczyć", jak celnie to określił Ryszard Skwarski (1990, s. 70), jeden $\mathrm{z}$ reprezentantów „młodzieżowego buntu” w PAX-ie. Granicę tych zmian jeszcze przed sierpniem $1980 \mathrm{r}$. trudno było precyzyjnie określić, tym bardziej, że w kierownictwie stowarzyszenia znajdowali się obrońcy status quo (Przetakiewicz, Stefanowicz i Wójcik). Z jednej strony PAX zabiegał o wiarygodność społeczną i nową tożsamość ideowo-polityczną stowarzyszenia, z drugiej nie chciał rezygnować ze starej tezy Piaseckiego, żeby „rewolucyjne siły spirytualistyczne” przeniknęły do „obozu zwycięskiej rewolucji”. Chodziło więc o przekonanie do socjalizmu nie tylko „wszystkich wątpiących”, ale i Kościół. W konsekwencji komuniści utraciliby monopol i musieli podzielić się władzą z PAX-em, wówczas jedynym konstruktywnym ruchem katolickim. Również we wszystkich analizach programowych dotyczących spraw międzynarodowych, polityki zagranicznej, a zwłaszcza tzw. sprawy niemieckiej, linia PAX-u pozostała niezachwiana. Nie podlegało dyskusji, że najważniejszym i niezmiennym sojusznikiem Polski jest ZSRR, rzeczywisty gwarant naszych granic, zwłaszcza granicy zachodniej na

9 Zob.(11 III 1979) „Kierunki”, nr 10, s. 2; R. Reiff (21 I 1979, s. 2); (8 VII 1979) „Kierunki”, nr 27, s. 2; (21 X 1979) „Kierunki”, nr 42, s. 2; (9 XII 1979) „Kierunki, nr 49, s. 2. Zob. też polemika: J. Wójcik (25 XI 1979, s. 1, 7). 
Odrze i Nysie Łużyckiej. Nie kwestionowano też „patriotycznego obowiązku” współdziałania z krajami demokracji ludowej w ramach sojuszów militarnych, ekonomicznych i politycznych (Układ Warszawski i RWPG). Znaczna część prasowych, publicystycznych wypowiedzi z przełomu 1979/1980 r. nie różniła się znacząco od tych z czasów wcześniejszych. Tutaj „rewolucji”, choćby semantycznej, nie było. Wszyscy mieli jednak świadomość, że o polityce nie decydują tylko „słowa”.

Wydaje się, że szkoła chłodnego realizmu B. Piaseckiego, którym najczęściej uzasadniano bezgraniczne podporządkowanie się kolejnym ekipom rządzącym, przestała się bronić. Zwłaszcza działacze terenowi i paxowska „młodzież” nie zamierzała już słuchać jałowych ideologicznych teorii i ich filozoficznych uzasadnień. Nie wszystkich również przekonywała, powtarzana na spotkaniach szkoleniowych, dyskusjach, które odbywały się w rozmaitych gremiach, teza o niezmienności i ponadczasowości (w pewnym sensie również uniwersalności) „szkoły Dmowskiego". Zaczęto na razie jeszcze delikatnie formułować wnioski, że trzeba zmienić nie tylko oficjalny język, jakim dotąd posługiwało się stowarzyszenie. Owszem PAX miał nadal pozostać zarówno strategicznym, jak i moralnym sojusznikiem PZPR, ale sojusznikiem rzeczywistym i autentycznym, posiadającym swoją wyraźnie odrębną tożsamość, podmiotowość i własne zaplecze społeczne. Ogromną wagę przywiązywano również do rehabilitacji wizerunku stowarzyszenia (poniekąd również postaci Piaseckiego) w oczach Kościoła. R. Reiff w swoich wystąpieniach mówił o dialogu, współdziałaniu, wsłuchiwaniu się w głos Prymasa Stefana Wyszyńskiego. Pojawiła się też nowa formuła - „łączność”, co odnoszono do łączności z polskim Kościołem, przede wszystkim w sprawach katolickiej nauki społecznej ${ }^{10}$. W każdym razie Reiff liczył na poprawę stosunków z kościołem. 29 marca 1979 r. został zaproszony przez Prymasa Wyszyńskiego na prywatną audiencję. Klimat rozmowy nie był tutaj najistotniejszy. Z oczywistych względów nie można było mówić ani o przełamaniu lodów, ani o współdziałaniu. Reiff tłumaczył Prymasowi, że zaangażowanie PAX-u po stronie socjalizmu to tylko taktyka, a deklarowana wierność socjalizmowi to jedynie „barwy ochronne” ${ }^{11}$. Najważniejsze było jednak symboliczne znaczenie tej audiencji, przypomnijmy pierwszego od

10 Wśród licznych artykułów prasowych z tego czasu (styczeń - sierpień 1980) można było zauważyć zapowiedź ewolucji ideowo-politycznej ruchu. Zob. np. (3 II 1980) „Kierunki”, nr 5, s. 1-2; (30 III 1980) „Kierunki”, nr 13, s. 1, 3; (6 IV 1980) „Kierunki”, nr 14, s. 2; (13 IV 1980) „Kierunki”, nr 10, s. 1-2.

11 Do kolejnego spotkania doszło w lipcu 1980 r. Por. (6 VII 1980) „Kierunki”, nr 27, s. 1. 
1953 r. spotkania przewodniczącego PAX-u z Prymasem. Nie było to rzecz jasna ostatnie spotkanie Prymasa z politykami PAX-u, co szybko zaowocowało i Prymas Wyszyński zaprosił przewodniczącego PAX-u na spotkanie z Janem Pawłem II, podczas jego pierwszej pielgrzymki do ojczyzny ${ }^{12}$. Kościół nabierał wobec nowego kierownictwa PAX-u coraz większego zaufania. W publicystyce na łamach „Słowa Powszechnego” i „Kierunków” drukowano najważniejsze wypowiedzi Stefana Wyszyńskiego (homilie, orędzia, listy, etc.), pisano o jego roli we współczesnej historii, niezłomności i trosce o rodzimą religijność (np. kult maryjny, katolicyzm ludowy). Reiff miał świadomość, że będzie musiał znaleźć jakąś formułę pośrednią między dotychczasowym zaangażowaniem socjalistycznym a działalnością, która byłaby zgodna z nauczeniem Kościoła.

Kierownictwo PAX-u, z większą niż dotąd odwagą wyrażało swoje opinie na temat kryzysu społeczno-gospodarczego. 11 listopada 1979 r., podczas ogólnopolskiej narady przewodniczących oddziałów miejskich PAX, Reiff co prawda pochlebnie oceniał zapowiedziany późną jesienią przez Gierka „program naprawczy", ale zarazem zwracał uwagę na co najmniej trzy płaszczyzny kryzysu: moralną, polegającą na obojętności i braku zaangażowania obywateli w sprawy publiczne; polityczną, wyrażającą się brakiem więzi między władzą a partią, i gospodarczą, wyrażającą się zmożonym wysiłkiem inwestycyjnym, niedostatecznym wykorzystaniem zaciągniętych kredytów zachodnich, niegospodarnością i marnotrawstwem. Reiff podkreślał, że popełniono niedopatrzenia w zakresie planowania inwestycyjnego, wzmożonego wysiłku industrializacyjnego, kosztem polityki społecznej, budownictwa mieszkaniowego, służby zdrowia, edukacji i bezpieczeństwa pracy. Zrozumiała wydawała się więc - stwierdzał przewodniczący PAX - coraz większa niecierpliwość społeczeństwa. Osobnym problemem, na który zwrócił uwagę, była fatalna polityka informacyjna władz, jednostronna, wypełniona sloganami, niepotrafiąca wyjaśnić społeczeństwu rzeczywistych źródeł kryzysu, eksponująca jedynie „osiągniecia w budowie socjalizmu” („Kierunki”, 6 I 1980, nr 1, s. 1, 3). Przemówienie Reiffa wywołało konsternację i wyraźne poirytowanie w aparacie partyjnym, stąd zostało wstrzymane przez cenzurę i opublikowane „po korektach” ze znacznym opóźnieniem.

12 Prasa paxowska zamieściła dziesiątki relacji i komentarzy w związku pierwszą pielgrzymką Jana Pawła do ojczyzny [(3 VI 1979) „Kierunki”, nr 22 (24 VI 1979)]. „Kierunku”, nr 25]. Pielgrzymkę podsumował R. Reiff w referacie wygłoszonym na spotkaniu oddziałów wojewódzkich Stowarzyszenia PAX. Por. R. Reiff. (1 VII 1979, s. 3). 
Głosów krytycznych wobec władz nie dało się jednak w stowarzyszeniu zagłuszyć. Widać było doskonale, że stowarzyszenie deklarujące wierność wskazaniom Piaseckiego faktycznie wchodziło w nowy etap swojej działalności i pracy ideowo-programowej. Kryzys społeczno-ekonomiczny, aktywność środowisk opozycji demokratycznej, wreszcie również wybór „papieża - Polaka” i jego pierwsza pielgrzymka do kraju aktywizowały struktury młodzieżowe w PAX-ie. Już w połowie lat 70. można było tam zaobserwować ideowy ferment. Źródłem, a zarazem katalizatorem zmian był wówczas Centralny Ośrodek Szkolenia Kadrowego (COSK), czyli inaczej „wydział młodzieżowy” PAX. Dotychczas ośrodek tonął w jałowych, nie dla wszystkich zrozumiałych dyskusjach doktrynalnych i właściwie spełniał dwie funkcje: był miejscem transmisji ideologii PAX i skutecznym „narzędziem” indoktrynacji młodych. Teraz miał się stać katalizatorem kształcenia autentycznego i niezależnego myślenia politycznego. Członkowie COSK: Przemysław Hniedziewicz, Andrzej Kostarczyk, Jan Król, Zygmunt Maria jr. Przetakiewicz, Romuald Szeremietiew, domagali się pokoleniowych zmian w stowarzyszeniu, wewnątrzśrodowiskowej demokracji, zerwania z nomenklaturą, zbliżenia do Kościoła, zerwania z linią bezgranicznego podporządkowania się partii i uczynienia z PAX-u partnerskiej wobec PZPR siły. „Frondyści” mieli dość silną pozycję w „terenie”, np. w: Poznaniu, Szczecinie, Tarnobrzegu, Gorzowie Wielkopolskim, Lesznie, Lublinie, Wrocławiu, Siedlcach, Łomży, Łodzi, Legnicy i innych miastach (por. zwłaszcza: Kuta, 2010, s. 59-60; Waligóra, 2004, s. 329-339; Marcinkiewicz, 2010, s. 167-194; Rymar, 2010, s. 427-435; R. Szeremietiew, 1993, s. 35-43).

Od samego początku nie było to środowisko pod względem ideowym jednolite i spoiste. Sięgano tam do różnych tradycji i doświadczeń: od katolickiej, narodowej, piłsudczykowskiej po socjalistyczną (socjaldemokratyczną). Z uwagą przyglądano się analizom partyjnych, liberalnych pragmatyków z Konserwatorium „Doświadczenie i Przyszłość”, nawiązywano kontakty z grupami opozycyjnymi. R. Szeremietiew i środowisko, które wokół siebie zbudował, podjęło współpracę z Ruchem Obrony Praw Człowieka i Obywatela, a następnie z Konfederacją Polski Niepodległej, za co w 1978 r. został (wraz z innymi działaczami) wyrzucony z PAX-u (Waligóra, 2004, s. 329-339; Szeremietiew, 1993, s. 35-43; Dudek, 1990, s. 327).

Przed sierpniem 1980 r. ferment zainicjowany przez młodych przybrał na sile. Daleka od paxowskiego żargonu ideologicznego młodzież domagała się zmian, rozliczenia z własną historią, likwidacją „absolutyzmu biurokratycznego”, uniezależnienia się od PZPR, autentycznego uczestniczenia w dialogu z różnymi siłami 
społecznymi. Trzon „młodzieżowego buntu” tworzyli wówczas: J. Król, P. Hniedziewicz, A. Kostarczyk, Leszek Horyński, Henryk Jerzmański, Anna Litwiniuk, Eugeniusz Aleksandrowicz, Ryszard Czabański, Elżbieta Czarnecka, Wojciech Janicki, Andrzej Hagmajer (syn Jerzego Hagmajera), Jarosław Piwar, Jarosław Walentynowicz, Jerzy Skwara, Jarosław Szczepański, Szymon Giżyński i Z.M. jr Przetakiewicz ${ }^{13}$. Wkrótce wielu z nich rozpocznie współpracę z „Solidarnością”. Działacze PAX-u starszej generacji, najbliżsi współpracownicy Piaseckiego, odnosili się do rzeczników „młodego buntu” z dużą niechęcią i ignorancją. Doskonale oddają to słowa Józefa Wójcika (2013, s. 233-234), który w swoich „Dziennikach”, pod datą 15 II 1976 r., notował: „Ci młodzi ludzie sprawiają na mnie wrażenie chorych intelektualnie, myśmy w ich wieku coś chcieli, widzieliśmy problemy, drżeliśmy o kulturę narodową polską. To aż kipiało w nas. Szukaliśmy wyjścia.

13 Grupa „młodzieży” określana w PAX-ie mianem „rewizjonistów” zamierzała przede wszystkim zreformować stowarzyszenie „od środka”. Było to jednak środowisko pod względem ideowo - politycznym mocno eklektyczne, dalekie od „endeckiego” rytu, który charakteryzował „pierwsze pokolenie” PAX-u. Sojusz z Rosją (ZSRR) traktowano jako rezygnację z niepodległości, a podporządkowanie się partii jako niezrozumiały, chłodny realizm, graniczący z kolaboracją. Głoszonej przez PAX koncepcji „jedności ideowo-politycznej” przeciwstawiano pluralizm i demokratyzację. Tylko socjalizm uznawano za wartość uniwersalną, synonim sprawiedliwości społecznej i demokracji. Trzonem tej grupy były kadry Centralnego Ośrodka Szkolenia Kadr, gdzie w 1979 r. Reiff usunął komisarycznego kierownika Wincentego Lewandowskiego i na jego miejsce wprowadził młodego Wiktora Szwechowicza, wówczas jeszcze studenta. Z „rewizjonistami” związali się również młodzi działacze oddziałów wojewódzkich stowarzyszenia i klubów „Słowa Powszechnego”. Swoistym „laboratorium” idei, miejscem dyskusji były nie tyko spotkania organizacyjne COSK, ale także organizowane cyklicznie sympozja COSK w Halinie i Ojrzanowie oraz tzw. Tygodnie Eklezjologiczne w Lublinie. Zapraszano na nie ludzi znanych, by wspomnieć o: ks. Józefie Tischnerze, Andrzeju Grzegorczyku, Tadeuszu Mazowieckim, Marianie Marku Drozdowskim, Andrzeju Tymowskim, Jerzym Łojku, Leszku Moczulskim, Andrzeju Zakrzewskim, Stefanie Kieniewiczu, Krzysztofie Mętraku, Janie Strzeleckim, Bohdanie Urbankowskim, a także cieszących się dużym wśród „młodych” autorytetem działaczy PAX: Mikołaju Rostworowskim i Zygmuncie Lichniaku. Por. Z.M. jr. Przetakiewicz, (2016, s. 46-51); Skwarski (1990, s. 93-98). W 1981 r. COSK został zastąpiony przez Krajowy Zespół Młodych. Na szczeblu wojewódzkim działały natomiast Wojewódzkie Zespoły Młodych. Pierwsza ogólnopolska sesja KZM odbyła się w dniach 4-6 XII 1981 r. Na przewodniczącego wybrano Szymona Giżyńskiego. W przyjętej rezolucji solidaryzowano się z niezależnym ruchem studenckim. Przyjęto również uchwały o powołaniu Klubów Demokracji Polskiej oraz cyklicznego biuletynu KZM. Młodzi publikowali również w prasie stowarzyszenia teksty, w których domagali się odbudowy autentycznej samorządności. Część z nich wyraźnie sympatyzowała nie z dziedzictwem narodowo-radykalnym, ale doktryną demokratycznego socjalizmu. Por. np. W. Szwechowicz (15 VI 1980, s. 5); Sz. Giżyński (15 VI 1980, s. 5); (13 X 1980) „Słowo Powszechne”, nr 222, s. 5-6; (19 XI 1980) „Słowo Powszechne”, nr 251, s. 3; Szwechowicz (5 IV 1981, s. 8); Szwechowicz (3 V 1981, s. 9); Szwechowicz (31 V 1981, s. 8). 
Oni nie widzą, ani problemów, ani o nic nie walczą. To chyba wpływ czasów, ale także ich wychowania szkolno-uniwersyteckiego pseudointelektualnego".

W czerwcu 1980 r. podczas Walnego Zgromadzenia Stowarzyszenia PAX przyszedł czas na bilans półtorarocznej działalności ruchu pod nowym kierownictwem. W oficjalnych przemówieniach oponentów Reiffa (Przetakiewicz i Stefanowicz) kurtuazyjnie wyrażano lojalność z linią PAX-u, zwłaszcza z działalnością mającą na celu upowszechnienie treści religijno-moralnej pontyfikatu Jana Pawła II i nauki Prymasa Tysiąclecia. Pojednawcze w swojej wymowie wypowiedzi „konserwatystów” świadczyły o tym, że nie mieli oni zamiaru prowadzić wewnątrzśrodowiskowej wojny. W przyjętych rezolucjach pozjazdowych wyrażano pełną akceptację dla programu ideowego Bolesława Piaseckiego. Zdecydowano również, że wydany zostanie zbiór artykułów publicystycznych Piaseckiego z lat 1945-1960 pod wspólnym tytułem „Kierunki” ${ }^{14}$. O wiele ciekawsze od oficjalnych dokumentów i rezolucji okazały się wybory do ciał statutowych stowarzyszenia. Przewodniczącym PAX-u został wybrany przez aklamację Reiff, wiceprzewodniczącymi: Stefanowicz, Wrzeszcz i Przetakiewicz, z którymi jeszcze teraz Reiff nie zamierzał się rozprawić. W ścisłym prezydium przeważali reprezentanci „zachowawczego centrum”. Rzecznicy zmian i odnowy mogli jedynie liczyć na: Króla, Jerzego Ślaskiego i Piotra Gołębiewskiego. Poparcie Reiffa i Mikołaja Rostworowskiego (patronował „zbuntowanej” młodzieży), uzyskali również nowo wybrani do władz PAX-u „rewizjoniści”: Aleksandrowicz, Hniedziewicz, Król, Szwechowicz, Edward Antończyk, Ryszard Rowiński i Tadeusz Swat. W ten sposób na kilka dni przed sierpniem 1980 r. w stowarzyszeniu PAX nie doszło do przesilenia i utrzymano równowagę sił.

W lipcu 1980 r. „Słowo Powszechne” wydrukowało obszerny artykuł Reiffa pt. „Tożsamość narodu podstawą jedności wszystkich Polaków”. Można w nim było dostrzec nowe impulsy w myśleniu politycznym. Po pierwsze, Reiff odmiennie od Piaseckiego nie posługiwał się już formułą państwa, którą zastąpił pojęciem „narodu” lub „społeczeństwa”. Oceniając dotychczasową politykę gospodarczą ekipy Gierka, był stonowany, a momentami nawet życzliwy, oceniając, że „nowa strategia” ekonomiczna może uzdrowić system, ale pod kilkoma warunkami. W tym miejscu pozostawał konsekwentny. Proponował po raz pierwszy, w sposób zdecydowany poszerzenie bazy społecznej, nawiązanie rzeczywistego

${ }^{14}$ W rezolucji pozjazdowej zarząd PAX został również zobowiązany do powołania Ośrodka ds. Badania Chrześcijańskiej Myśli Społecznej. Zob. (15 VI 1980) „Kierunki”, nr 24, s. 1; (15 VI 1980) „Kierunki”, nr 24, s. 2. 
dialogu między partią a różnymi ośrodkami społecznymi. Wzywał do nawiązania moralnej więzi między władzą a rozgoryczonym pogłębiającym się kryzysem społeczeństwem, nie wykluczając ze współdziałania Kościoła, którego rola i pozycja w tym czasie szczególnie wzrosła ${ }^{15}$.

Gdy w sierpniu 1980 r. wybuchły strajki na Wybrzeżu, R. Reiff przebywał w Bukareszcie. W oczekiwaniu na rozwój wypadków przebywające w kraju kierownictwo Stowarzyszenia PAX całkowicie się pogubiło, nie potrafiąc zająć jednoznacznego stanowiska wobec narastającego w kraju kryzysu. Reprezentanci orientacji „zachowawczej” zgodnie z taktyką przyjętą w przeszłości niemal zgodnie stanęli po stronie KC PZPR. Najpierw Z. Przetakiewicz w telewizji polskiej stanął w obronie atakowanego przez „robotniczą ekstremę” Edwarda Gierka. Następnie J. Stefanowicz, wówczas redaktor naczelny „Słowa Powszechnego” w artykule pt. „W słusznym kierunku” kreował pierwszego sekretarza KC PZPR na męża stanu, zatroskanego o losy ojczyzny ${ }^{16}$. Ryszard Skwarski nie bez racji sugerował, że wśród dawnych stronników Piaseckiego liczono wówczas na druk artykułu programowego, w którym stowarzyszenie, chcąc zachować własny stan posiadania, poparłoby władze i rozprawiło się z „wichrzycielami” wspieranymi przez „wrogie Polsce Ludowej ośrodki zachodniego imperializmu”. Oczywiście o drugim „,instynkcie państwowym ${ }^{17 ”}$, tak jak to było w październiku $1956 \mathrm{roku}$

15 Artykuł najpierw wydrukowały „Kierunki” - R. Reiff (20 VII 1980, s. 1, 3), a następnie „Słowo Powszechne" (21-22 VII 1980, s. 3). Zob. również: R. Reiff (21-22 VII 1980, s. 1); Z. Komender (30 VII 1980, s. 3).

16 J. Stefanowicz (21 VIII 1980, s. 1). Między 14 a 21 sierpnia prasa Stowarzyszenia PAX drukowała głównie oficjalne przemówienia członków KC PZPR, m.in. Edwarda Gierka i Edwarda Babiucha.Zob. (18 VIII 1980) „Słowo Powszechne”, nr 178, s. 1; (20 VIII 1980) „Słowo Powszechne”, nr 180, s. 1-2; Z. Komender (1 IX 1980, s. 1-2).

17 Przez tytułowy „instynkt państwowy” B. Piasecki rozumiał zdolność narodu do formułowania w „każdej epoce historycznej intelektualnego wyrazu konkretnej miłości ojczyzny i konkretnej miłości słusznej sprawy ludzkości”. W dalszej jego części domagał się uczciwej oceny całego dorobku Polski Ludowej, utrzymania „ścisłego sojuszu państwowego z narodami Związku Radzieckiego”, rozwiązania oraz sprecyzowania bieżącego programu rządzenia, wreszcie również określenia problemów ideologicznych - ustalenia zasad tzw. teorii socjalizmu. Najwięcej wątpliwości budziło użyte przez Piaseckiego sformułowanie: „jeśli nie ujmiemy dyskusji w ramy odpowiedzialności, zamiast demokratyzacji spowodujemy procesy konieczności brutalnego realizowania racji stanu w okolicznościach podobnych do ogłoszenia stanu wyjątkowego". Powszechnie odebrano te słowa jako wezwanie do puczu, postawienie na frakcję „natolińską," ze strony której spodziewano się, że przygotowuje zamach stanu. Por. B. Piasecki. (21 X 1956, s. 1-2). Prawie wszystkie te ataki prasowe na PAX zostały kilka miesięcy później opublikowane w miesięczniku „Życie i Myśl” (w rubryce: „Dokumenty”). Por. (1957) „Życie i Myśl”, nr 4-5, nr 1. Zob. również: T. Sikorski (2016, s. 27-44). Publikacja artykułu przyśpieszyła dekompozycję w środowisku PAX i wystąpienie tzw. secesji (m.in. Andrzej Micewski, 
nie było mowy. Nikt nie zamierzał tym razem włączać się w partyjne walki frakcyjne, oczekiwano jedynie jednoznacznej prorządowej deklaracji. Zamiast tego w „Słowie Powszechnym” wydrukowano list „weteranów” PAX-u: Jana Dobraczyńskiego, znanego i cenionego pisarza katolickiego, oraz Witolda Olszewskiego, który w tym czasie publikował w prasie ruchu postępowych katolików. Obaj w przeszłości związani byli z ruchem narodowym, co - jak się okazało - nie było bez znaczenia. Za pośrednictwem dziennika stowarzyszenia zwracali się oni „wychowani w szkole Dmowskiego” o zrozumienie dla realizmu politycznego, co oznaczać musiało definitywne potępienie „robotniczego buntu”, zagrażającego „jedności moralno-politycznej” partii z narodem ${ }^{18}$. Wydawałoby się, że z pozoru „niegroźny” tekst (bo „tylko” list „weteranów”) wywołał prawdziwe tąpnięcie „dołów”. Przeciwko niemu oponował również Reiff i „młodzi” z COSK oraz wojewódzkich „ogniw” stowarzyszenia. Najpierw krytycznie na list Dobraczyńskiego i Olszewskiego odpowiedziała redakcja „Wrocławskiego Tygodnika Katolickiego”, następnie kolegialnie zarząd PAX-u przyjął deklarację, że była to jedynie osobista i indywidualna ocena wydarzeń sierpniowych Dobraczyńskiego i Olszewskiego, odmienna od odczuć i nastrojów w stowarzyszeniu. Parcie „terenu” na „centrale” było bowiem tak silne, że kierownictwo z Reiffem na czele musiało brać to pod uwagę. W czasie, gdy fala strajków objęła cały kraj, w stowarzyszeniu wrzało. Pozycja obrońców dawnej strategii Piaseckiego topniała z dnia na dzień. Do końca o jej słuszności przekonywali jedynie Wójcik i Przetakiewicz. Neutralne stanowisko zajmował ich dawny stronnik J. Stefanowicz. W artykule z 2 września 1980 r. pt. „Witamy porozumienie”, z dużą ulgą, a zarazem życzliwością przyjął fakt podpisania porozumień w Szczecinie (30 VIII) i Gdańsku (31 VIII) ${ }^{19}$. Jednocześnie zaznaczył, że jest to jedynie „pierwszy krok” do „odnowy” i autentycznej

Jan Frankowski, Konstanty Łubieński), która później otrzymała koncesję na utworzenie własnego tygodnika „Za i Przeciw” a następnie powołała Chrześcijańskie Stowarzyszenie Społeczne.

18 W liście J. Dobraczyńskiego i W. Olszewskiego można było przeczytać: „Wychowani w szkole Romana Dmowskiego zwracamy się do Panów (Prezydium Zarządu Stowarzyszenia PAX i Katolicko-Społecznego Koła Poselskiego Znak - przyp. autora) mających jak mniemamy zrozumienie dla naszego sposobu myślenia, by Wasza aktywność zbiorowa w tej nowej sytuacji przyczyniła się do utarcia drogi dla szkoły polskiego realizmu narodowego. Szkoła ta w równym stopniu uwzględnia wymogi racji stanu, zobowiązania międzynarodowe, podstawowe sojusze Polski jako jedną z podstaw porządku europejskiego, a także poczucia godności narodowej i indywidualnej, elementarnej sprawiedliwości pośród Polaków oraz zbiorowej odpowiedzialności za jutro naszej Ojczyzny". Za: W. Olszewski, J. Dobraczyński (1 IX 1980, s 2).

19 Po ukazaniu się tekstu Stefanowicza podpisano jeszcze porozumienie w Jastrzębiu Zdroju - 3 IX 1980 r. i w Hucie Katowice w Dąbrowie Górniczej - 11 IX 1980 r. 
dyskusji społecznej, która powinna się odbyć już na najbliższej sesji Sejmu ${ }^{20}$. W okresie strajków w niezwykle trudnej sytuacji znajdowała się prasa stowarzyszenia, drukując najczęściej wcześniej otrzymane informacje Polskiej Agencji Prasowej. Dotyczyło to również wypowiedzi Prymasa Wyszyńskiego ${ }^{21}$. Jednym z nielicznych wyjątków był artykuł z 26 VIII „Powaga chwili i zapowiedź zwrotu”. Był to tekst nawiązujący do IV Plenum KC PZPR (24 VIII 1980 r.) ${ }^{22}$. Co prawda PAX aprobował w tym artykule zapowiedź powrotu do „pogrudniowej polityki”, to jednak wysuwał również postulaty rzetelnej oceny stanu polskiej gospodarki, nawiązania rzeczywistego dialogu ze społeczeństwem oraz realizacji zasady sprawiedliwości społecznej w zakresie polityki płacowej i kadrowej („Słowo Powszechne", 27 VIII 1980, nr 185, s. 1).

Po podpisaniu „porozumień sierpniowych” w Szczecinie i Gdańsku cenzura wobec prasy paxowskiej nieco zelżała. 4 września 1980 r. zebrał się po raz pierwszy od wybuchu strajków zarząd PAX-u. Obrady otworzył Reiff, który $\mathrm{w}$ referacie programowym ocenił sytuację polityczną $\mathrm{w}$ kraju. Wyraził dumę ze społeczeństwa polskiego, dojrzałość „klasy robotniczej”, która potrafiła znaleźć siłę i odwagę do dialogu z partią. Uważał, że jest to historyczny krok w kierunku stabilizacji i wspólnej odpowiedzialności za kraj. Jednocześnie stwierdzał, że dotychczasowa analiza historycznych kryzysów w Polsce Ludowej powinna uczyć, iż za samym faktem porozumienia powinna iść „praktyka realizacyjna”, czyli rzetelna i głęboka ocena kryzysu oraz konkretne decyzje. Reiff wytknął też partii rozliczne błędy, posiłkując się najważniejszymi dokumentami programowymi KC PZPR, przyjmowanymi na kolejnych plenach partyjnych. Za najważniejsze uznawał całkowite rozminięcie się programu gospodarczego ekipy Gierka z oczekiwaniami społecznymi, w takich dziedzinach jak: budownictwo mieszkaniowe, polityka społeczna i prorodzinna, służba zdrowia, handel i usługi, czy oświata. Należało również zlikwidować wszelkie nieuzasadnione przywileje i dodatkowe dochody uzyskiwane nie poprzez uczciwą i wydajną pracę, ale

20 Stef. [J. Stefanowicz] (2 IX 1980, s. 1). Zob. również: (2 IX 1980) „Słowo Powszechne”, nr 189, s. 1-2; (Mos.). (3 IX 1980, s. 1); A. Radajewski (7 IX 1980, s. 1).

${ }^{21}$ Zob. np. (20 VIII 1980) „Słowo Powszechne”, nr 180, s. 1-2; Dopiero w końcu sierpnia 1980 r. drukowano w całości lub we fragmentach wypowiedzi Prymasa. Np. (25 VIII 1980) „Słowo Powszechne”, nr 183, s. 1; (j). [Janusz Stefanowicz] (27 VIII 1980, s. 5); (27 VIII 1980) „Słowo Powszechne”, nr 185, s. 5. (30 VIII 1980) „Słowo Powszechne”, nr 186, s. 1-2; (1 IX 1980) „Słowo Powszechny”, nr 188, s. 1, 3; (5-7 IX 1980) „Słowo Powszechne”, nr 192, s. 7; S. Wyszyński (7 IX 1980, s. 1, 3).

22 „Słowo Powszechne” niemal cały numer (184), z 26 VIII 1980 r. poświęciło obradom IV Plenum KC PZPR. Wydrukowano przemówienia plenarne, ogłoszono skład nowego KC, wraz z życiorysami jego członków. 
przynależność do określonych układów. Za szkodliwy dla dialogu społecznego uznał styl propagandy i polityki informacyjnej, tuszującej zaniedbania gospodarcze, ignorującej rzeczywiste odczucia społeczne. Sprawą najwyższej wagi dla Reiffa był również postęp w autentycznym rozwoju „demokracji socjalistycznej”, polegający na zerwaniu $\mathrm{z}$,teatralizacją życia publicznego", poszerzeniu form dialogu i współdziałania dla wspólnego dobra. Po raz pierwszy przewodniczący stowarzyszenia PAX opowiedział się również publicznie za poszerzeniem „frontu zaangażowanych patriotycznie grup bezpartyjnych”, w tym „bezpartyjnej inteligencji”, środowisk katolików świeckich i Kościoła, który wykazywał się dużą roztropnością i troską o naród. Reiff zapowiedział także, że ruch postępowych katolików włączy się w realizację „porozumień sierpniowych”, co odczytano jako poparcie dla powstających niezależnych i samorządnych związków zawodowych ${ }^{23}$. Referat Reiffa miał zapoczątkować wewnątrzśrodowiskową dyskusję nad ewolucją ideowo-programową stowarzyszenia. Już dzień później 5 września, podczas sesji Sejmu przewodniczący PAX-u powtórzył najważniejsze postulaty ruchu, po raz kolejny diagnozując podłoże kryzysu, punktując błędy popełnione przez partię, wreszcie również wzywając do kontynuowania dialogu i poszerzenia „bazy rządzenia” o środowiska „pozapartyjne”24.

Wewnętrzne spory w PZPR, które ujawniły się na VI Plenum KC PZPR (5 IX 1980 r.), głosy sceptyczne wobec „odnowy”, przypisujące organizację strajków „siłom antysocjalistyczym”, skłoniły Reiffa do zwołania kolejnego zarządu PAX-u na dzień 15 września ${ }^{25}$. Przewodniczący stowarzyszenia miał świadomość, że z jednej strony w partii znajdują się siły konserwatywne, które nie zamierzają kontynuować „linii porozumienia”, z drugiej strony także w PAX-ie są obecni krytycy jego nowej strategii, którą zaprezentował w referacie z 4 września. Reiff podkreślał, że strajkujący robotnicy nie zwrócili się przeciwko ustrojowi i socjalizmowi, ale upomnieli się o „sprawiedliwość społeczną” i podmiotowe prawa społeczeństwa. Zorganizowali się „oddolnie”, spontanicznie, bez żadnej inspiracji zewnętrznej, co zarzucał komitetom strajkowym „komunistyczny beton”. Kon-

23 Por. (8 IX 1980) „Słowo Powszechne”, nr 193, s. 1; R. Reiff. (8 IX 1980, s. 3-4; (18-19 X 1980) „Słowo Powszechne” nr 227, s. 1, 4; (18-19 X 1980) „Słowo Powszechne”, nr 227, s. 3-4; (20 X 1980) „Słowo Powszechne”, nr 228, s. 3-4; (14 IX 1980) „Kierunki”, nr 37, s. 1-2.

${ }^{24}$ Wypowiedzi niektórych parlamentarzystów zamieściło „Słowo Powszechne”. Por. (8 IX 1980) „Słowo Powszechne”, nr 193, s. 4; (9 IX 1980) „Słowo Powszechne”, nr 194, s. 4. Także (28 IX 1980) „Kierunki”, nr 39, s. 2.

25 Obradom VI Plenum KC PZPR poświęcono cały (218) numer „Słowa Powszechnego” z 7 X 1980 r. Zob. też komentarz: J. Stefanowicz. (8 X 1980, s. 1). 
struktywna i rzeczowa krytyka w ramach socjalistycznego dialogu nie miała nic wspólnego $\mathrm{z}$ antysocjalistycznym, wrogim wobec państwa nastawieniem, a wręcz odwrotnie, świadczyła o dojrzałości i odpowiedzialności ruchu protestu społecznego, który naciskał na władze, mając do tego nie tylko prawo, ale i obowiązek. Reiff uważał, że to przede wszystkim partia powinna zrobić „rachunek sumienia” i „uderzyć się we własne piersi”, pracować nad alternatywnymi programami społeczno-politycznymi, uwzględniającymi nie tyko makroekonomiczne wskaźniki, ale również oczekiwania społeczne, nie mniej ważne dla uzdrowienia sytuacji. To partyjni oportuniści, karierowicze, dogmatycy i biurokraci nastawieni na odwet i rewanż są przeciwnikami socjalizmu i postępu - przekonywał ${ }^{26}$. Obradujący w 53 osobowym składzie zarząd w pełni zaaprobował linię programową PAX.

W końcu października 1980 r. Reiff ponownie zabrał głos. Był to moment trwającego „kryzysu rejestracyjnego”, kiedy władze domagały się umieszczenia w statucie NSZZ „Solidarność” zapisu o przewodniej roli partii, czemu liderzy związkowi się sprzeciwiali, argumentując, że nowe związki mają być niezależne i samorządne, a więc niezależne od PZPR.W artykule „Czas próby” Reiff potwierdził potrzebę gruntownej przebudowy państwa („poszerzenia bazy socjalizmu”) oraz sposobów działania partii rządzącej. Uważał, że partia nie odgrywa tylko i wyłącznie „roli przewodniej”, ale powinna reprezentować interesy i oczekiwania całego narodu. Twierdził dalej, że tradycyjna polska samorządność może się stać ważnym instrumentem demokratyzacji. Co oznaczało, że samorządne związki zawodowe oraz niezależne organizacje środowiskowe mogą tworzyć nową „oś pionową" struktur państwowych, nie zastępując jego konstytucyjnych organów [„Kierunki”, 9 XI 1980; „Słowo Powszechne”, 24-26 X 1980]27.

Dotychczasowe wypowiedzi Reiffa (z 4, 5 i 15 IX oraz 31 X 1980 r.) stanowiły integralną część wykładni ideowo-politycznej stowarzyszenia, która miała być realizowana przez zarząd i wszystkie ogniwa PAX-u. „Była to linia

26 (17 IX 1980) „Słowo Powszechne”, nr 201, s. 1; (19-21 X 1980). „Słowo Powszechne”, nr 203, s. 3-4. Także: (28 IX 1980). „Kierunki”, nr 39, s. 3; (26 X 1980) „Kierunki”, nr 43, s. 2. Krytyka referatu Reiffa: Z. Komender (5 X 1980, s. 1-2).

27 R. Reiff (24-26 X 1980, s. 3-4). Również: (9 XI 1980) „Kierunki”, nr 45, s. 1, 3. Artykuł R. Reiffa był polemiką z tekstami J. Stefanowicza (11-12 X 1980, s. 3) i Z. Czajkowskiego (13 X 1980, s. 1). Stefanowicz stwierdzał wprost, że państwa nie można zastąpić „federacją samorządów”, bo grozi to obumieraniem struktury państwowej. Zob. także inne teksty i przemówienia rozwijające przesłanie artykułu „Czas próby”: (2 X 1980) „Słowo Powszechne”, nr 213, s. 2; (10 X 1980) „Słowo Powszechne”, nr 220, s. 5; (10 X 1980) „Słowo Powszechne”, nr 220, s. 6; (30 X 1980) „Słowo Powszechne”, nr 236, s. 1-2; (j. ś.) [J. Ślaski] (31 IX-2 X 1980, s. 1); (6 XI 1980) „Słowo Powszechne”, nr 241, s. 2; (j.ś.). [J. Ślaski] (13 XI 1980, s. 1); (19 XI 1980) „Słowo Powszechne”, nr 251, s. 3. 
w pełni świadomego i rzetelnego opowiedzenia się za tym wszystkim, co w nurcie dokonujących się przemian było twórcze, konstruktywne i korzystne dla Polski i Polaków: za autentyczną demokratyzacją życia publicznego, z podmiotową rolą obywateli w państwie, za socjalizmem rozwojowym, wyrażającym i realizującym uprawnione postulaty wieloświatopoglądowego narodu. Była to również - dodajmy - linia potwierdzająca pryncypia ustrojowe PRL" - pisał po latach R. Reiff (1988, s. 38-39). Stowarzyszenie PAX zadeklarowało również swoje poparcie dla powstających związków zawodowych i udzielenie im pomocy personalno-lokalowej. Reiff był przekonany, że nowe niezależne syndykaty to nie tylko typowe związki zawodowe, ale ruch społeczny, który stanie się trwałym uczestnikiem „odnowy”, a jednocześnie siłą nacisku na władzę (czynnik kontroli społecznej), aby wyeliminować wszelką niesprawiedliwość i niepraworządność. W konsekwencji na terenie całego kraju rozpoczęła się spontaniczna akcja pomocy dla związku. W lokalach wojewódzkich i miejskich oddziałów stowarzyszenia zaczęły powstawać punkty informacyjno-konsultacyjne (Przemyśl, Szczecin, Bielsko-Biała, Legnica, Włocławek, Gliwice, Płock, Opole, Tarnobrzeg, Olsztyn, Leszno, Częstochowa) ${ }^{28}$. W lokalach stowarzyszenia (także w klubach „Kierunków” i „Słowa Powszechnego”) odbywały się nierzadko zebrania założycielskie MKZ, zebrania komisji zakładowych „Solidarności”, a działacze terenowi PAX zasilali nowo powstające związki zawodowe (Zob. szczególnie: Dworaczek, 2014, s. 291-294; Skwarski, 1990, s. 106-111; Reiff, 2007, s. 305; Przetakiewicz, 2016, s. 117-139). ${ }^{29}$ Z inicjatywy Zygmunta Marii jr. Przetakiewicza w Instytucie

28 Biorąc pod uwagę, iż terenowe struktury PAX liczyły 49 oddziałów wojewódzkich i ponad 300 ogniw terenowych niższego szczebla, było to ogromne zaplecze infrastrukturalne dla „Solidarności”.

${ }^{29}$ Wśród przykładów zaangażowania działaczy PAX-u w struktury NSZZ „Solidarność” można wymienić choćby uczestnictwo Andrzeja Drzycimskiego (wówczas redaktor „Wrocławskiego Tygodnika Katolików”) w prace gdańskiego prezydium MKZ (przed pewien okres zastępował nawet rzecznika prasowego MKZ Lecha Bądkowskiego). Maria Mrozińska, Ewa Górska i Grzegorz Fortuna współredagowali „Samorządność” - dodatek do „Dziennika Bałtyckiego”. Eugeniusz Matyjas był członkiem (przewodniczącym) „Solidarności” w Lesznie, Jarosław Szczepański w Rzeszowie, Edward Antończyk w Tarnobrzegu, Tomasz Klimański w Białej Podlaskiej, Kazimierz Switun w Katowicach i Jarosław Piwar w Szczecinie. Natomiast Zygmunt Maria Przetakiewicz jr jako przewodniczący organizacji zakładowej NSZZ „Solidarność” wszedł do zarządu regionu Mazowsze, a później, po wyjeździe z kraju, został kierownikiem Biura Informacyjnego „Solidarności” w Nowym Jorku. Przed opuszczeniem Polski napisał krytyczny list do władz PAX-u, który wydrukowała „Niezależność” [1981, nr 15], w którym poddał krytyce całą dotychczasową linię stowarzyszenia. Ostatecznie zarząd PAX-u przystał na prośbę Przetakiewicza i skreślił go z listy członków. Z M. Przetakiewicz jr. (2016), s. 117-206. 
Wydawniczym PAX udało się założyć zakładową strukturę NSZZ „Solidarność”. Podobne ogniwa powstawały również w oddziałach „terenowych” stowarzyszenia. Także prasa stowarzyszenia starała się na bieżąco informować o powstawaniu kolejnych struktur związkowych na terenie całego kraju, zamieszczała również wywiady z lokalnymi działaczami „Solidarności”, a nawet KSS KOR, których wcześniej zaciekle zwalczano ${ }^{30}$. Echa wsparcia PAX-u dla niezależnych związków zawodowych, a także ewolucja programowa, jaka dokonywała się w stowarzyszeniu, nie uszła też uwadze bezdebitowym pismom związkowym (głównie zakładowym), które życzliwie, a jednocześnie z ostrożnością wypowiadały się o zaangażowaniu kierownictwa PAX, które powoli „rehabilitowało” swój wizerunek środowiska w pełni lojalnego i bezkrytycznego wobec aparatu partyjno-rządowego.

Młodzi działacze PAX-u na fali posierpniowej odwilży spontanicznie włączyli się również w dyskusję nad potrzebą zmian w studenckim ruchu akademickim. Już we wrześniu COSK kolportował na uczelniach w całym kraju środowiskowy dokument $O$ samorządność studencką. Oświadczenie młodych działaczy PAX (19 IX 1980 r.), w którym podnoszono wiele spraw, przede wszystkim potrzebę zdemonopolizowania wpływów SZSP i zachowania autentycznej autonomii uczelni wyższych. W dokumencie nie wspomniano, co prawda, o właśnie formującym się Niezależnym Zrzeszeniu Studentów, ale domagano się utworzenia nowej niezależnej i samorządnej organizacji studenckiej (Dworaczek, 2014, s. 295-296) 31. Takie próby podjęto między innymi w Warszawie i Lublinie (na Katolickim Uniwersytecie Lubelskim). W dużych ośrodkach miejskich, gdzie mieściły się szkoły wyższe, działacze PAX- nawiązywali kontakt z miejscowymi komitetami założycielskimi NZS, organizowali dyskusyjne, spotkania z profesurą i władzami uczelni. Na przykład w Szczecinie Jarosław Piwar - szef tamtejszego

${ }^{30}$ Był to także efekt złagodzenia ingerencji cenzury po sierpniu 1980 r. Poza tym w redakcjach pism związanych z PAX-em doszło również do zmian i drobnych roszad personalnych. Na przykład w „Słowie Powszechnym” Janusza Stefanowicza (redaktora naczelnego), 20 X 1980 r. zastąpił Jerzy Ślaski - stronnik „frakcji reformatorskiej” R. Reiffa, a redaktorem tygodnika „Zorza” został Sławomir Siwek. Zob. np. (11-12 X 1980) „Słowo Powszechne”, nr 221, s. 1-2; A. Kot (27 X 1980, s. 3); (27 X 1980) „Słowo Powszechne”, nr 233, s. 1, 4; Z. Skrzypkowski (4 XI 1980, s. 3); (25 XI 1980) „Słowo Powszechne", nr 255, s. 1-2.

31 Już wiosną 1980 r., a więc jeszcze przed „gorącym sierpniem”, podczas sympozjum COSK podnoszono potrzebę stworzenie niezależnej od PZPR organizacji studenckiej, która mogłaby konkurować z SZSP. Wówczas członkowie zarządu „młodzieżówki” PAX - Piotr Gołębiowski i Szwechowicz - utrącili ten pomysł, uznając go za „rewolucyjny”, zagrażający linii programowej stowarzyszenia. 
WOSK - zorganizował w lokalu oddziału „Kierunków” otwartą dyskusję na temat samorządności studenckiej, w której wzięli również udział członkowie późniejszego NZS (Siedziako, 2009, s. 106-113). Również prasa stowarzyszenia z uwagą przyglądała się „ruchowi odnowy” w środowisku akademickim, solidaryzując się nawet ze strajkującymi studentami (jesień 1980 r.) $)^{32}$. Wykonywane w stosunku do NZS gesty pojednawcze nie wzbudzały jednak u wszystkich zaufania. Akademicy z NZS pamiętali jeszcze ciągle, jaką rolę odrywał PAX wcześniej i do jakiej ideowej tradycji sięgał. Dla wielu z nich Bolesław Piasecki był antybohaterem, symbolem serwilizmu wobec partii. Stąd między innymi odrzucono ofertę redakcji „Słowa Powszechnego”, aby NZS współredagował specjalną kolumnę studencką.

W ramach postulowanej przez PAX koncepcji „poszerzania społecznej bazy socjalizmu”, a więc wielonurtowego dialogu i współdziałania z różnymi środowiskami, nawiązano kontakt z Konserwatorium „Doświadczenie i Przyszłość” ${ }_{33}$ oraz Stowarzyszeniem Dziennikarzy Polskich, które na swoim nadzwyczajnym zjeździe 29 X 1980 r. podjęło rezolucję o poparciu przemian dokonujących się w kraju po sierpniu $1980 \mathrm{r}^{34}$. Ociepliły się również stosunki PAX-u z klubami inteligencji katolickiej i ruchem Znak. W „Słowie Powszechnym” informowano również o działalności i programie PZKS i ChSS. Drukowano też we fragmentach lub w całości najważniejsze przemówienia Prymasa Wyszyńskiego, nierzadko opatrując je pochlebnym komentarzem odredakcyjnym. W diagnozie sytuacji

32 Wśród licznych artykułów poświęconych temu zagadnieniu na uwagę zasługują: (J.R.) [J. Rowicki] (25 IX 1980, s. 1); M. Jaworska, M. Machnacki (25 IX 1980, s. 5); (26 IX 1980) „Słowo Powszechne”, nr 208, s. 1-2; (sas.) (1 X 1980, s. 1); J. Rowicki (2 X 1980, s. 3); (15 X 1980) „Słowo Powszechne”, nr 224, s. 1-2; (10 X 1980) „Słowo Powszechne”, nr 220, s. 1; M. Mochnacki, M. Jabłońska (23 X 1980, s. 4); G. Niegodzisz (18 XI 1980, s. 3); (19 II 1981) „Słowo Powszechne”, nr 35, s. 1-2; R. Łuczyński (19 II 1981, s. 3); A. Kot (23 II 1981, s. 1 -2); (j.ś.) [J. Ślaski] (28 IV 1981, s. 1); (12 X 1980) „Kierunki”, nr 41, s. 1, 5; S. Siwek (26 X 1980, s. 9); (15 III 1981) „Kierunki”, nr 11, s. 1, 4.

33 Działające w latach 1978-1982 Konserwatorium „Doświadczenie i Przyszłość” zostało powołane z inicjatywy Stefana Bratkowskiego i Bogdana Gotowskiego. Był to nieformalny klub dyskusyjny, w którym brali udział reprezentanci niezależnej inteligencji (także katolickiej) oraz reformatorskie środowiska partyjne. Już w maju 1979 r. w „Raporcie o stanie Rzeczypospolitej i drogach wiodących do jej naprawy" postulowano zmiany w zarządzaniu państwem, demokratyzację PZPR, wzmocnienie systemu przedstawicielskiego i samorządności oraz utworzenie autentycznych i niezależnych związków zawodowych. Po sierpniu 1980 r. część uczestników konserwatorium wsparła czynnie NSZZ „Solidarność”. Por. A. Friszke. (1994, s. 516-522); R. Kozioł (2001, s. 327-336); R. Kozioł (2002, s. 155-176).

${ }^{34}$ Do Zarządu Głównego i Rady Naczelnej SDP weszli również dziennikarze PAX: Jacek Moskwa i Sławomir Siwek. Por. (3 XI 1980) „Słowo Powszechne”, nr 238, s. 1-2; (j. ś.) [J. Ślaski] (4 XI 1980, s. 1). 
linia Episkopatu w wielu punktach była przecież zgodna $\mathrm{z}$ orientacją programową PAX.

W stowarzyszeniu PAX nie było jednak jednomyślności co do „programowego zwrotu" po sierpniu 1980 r. Przede wszystkim entuzjazm i zaangażowanie po stronie „Solidarności”, jakie obserwowaliśmy „w terenie”, nie pokrywały się do końca z nastrojami w warszawskiej centrali. Do tego dochodziły jeszcze różnice natury pokoleniowej. Starzy działacze PAX-u, wywodzący się jeszcze z narodowo-radykalnej „Falangi”, uważali, że kierownictwo stowarzyszenia popełnia błąd, „stawiając na Solidarność”, a w kwestiach doktrynalnych sprzeniewierzając się „Wytycznym” Bolesława Piaseckiego. Do ostatecznego rozprawienia się z „konserwatystami” miało dojść 20 października 1980 r. podczas zebrania zarządu stowarzyszenia. Programowy referat Reiffa pt. „Odpowiedzialność za naród i państwo" został przyćmiony wewnętrzną rozgrywką ${ }^{35}$. Postawiono wówczas wniosek o wersyfikacje personalną prezydium PAX-u. Była to gra o wielką stawkę. Reiff miał jednak świadomość, że może liczyć na paxowskie „doły” i młodzież z COSK. Ostatecznie po głosowaniu z zarządu zostali „wykluczeni”: „weterani”: Przetakiewicz, Hagmejer i Jerzy Rutkowski oraz Stefanowicz, który otrzymał najmniej głosów. Nadal jednak silną pozycję utrzymali zwolennicy Piaseckiego i jego długoletni współpracownicy: Zenon Komender, Józef Wójcik i Zbigniew Czajkowski. Reiff podziękował doświadczonym politykom za ich ponad 30-letnią działalność, eksponując przy tym świadomie przedwojenne związki Przetakiewicza, Hegmajera i Rutkowskiego z ruchem narodowo-radyklanym. W ten sposób - jak komentował to wydarzenie po latach Skwarski - została przecięta „pępowina łącząca Falangę z PAX”, a Bolesław Piasecki przestał być patronem stowarzyszenia [Skwarski, 1990, s. 111]. Do podobnych „czystek”

35 R. Reiff podniósł w referacie kwestię konieczności realizacji wszystkich porozumień sierpniowych i wrześniowych, rejestracji związku oraz odbudowy autentycznego samorządu wiejskiego (rolniczego). Krytycznie ocenił styl i metody kierowania środkami masowego przekazu, blokowania do nich dostępu działaczy związkowych. Jednocześnie przedstawił obszerną listę postulatów, które władze miały zrealizować, m.in.: poszerzenie bazy społecznej rządzenia, wprowadzenie w życie zasad sprawiedliwości społecznej, prowadzenie aktywnej polityki społecznej, odnowa kadr wszystkich szczebli władzy, zmiana stylu rządzenia (partnerskie relacje na linii społeczeństwo - władza), autentyczność funkcjonowania ciał przedstawicielskich i form społecznej samorządności, wyciągnięcie surowych konsekwencji personalnych wobec winnych nadużyć władzy i błędów prowadzących do kryzysu oraz opracowanie alternatywnego planu reformy gospodarczej. Zob. szerzej: (22 X 1980) „Słowo Powszechne”, nr 230, s. 1; (22 X 1980) „Słowo Powszechne”, nr 230, s. 1-2. Tam również nowy skład Prezydium Stowarzyszenia PAX, wraz z krótką charakterystyką członków. Zob. też: (2 XI 1980) „Kierunki”, nr 44, s. 2; (23 X 1980) „Słowo Powszechne”, nr 331, s. 3; Także: (2 XI 1980) „Kierunki”, nr 44, s. 3; Reiff (1988), s. 86. 
przez następne miesiące, do końca 1980 r., dochodziło również w strukturach wojewódzkich i miejskich stowarzyszenia, gdzie w zarządach przewagę uzyskiwali młodzi działacze angażujący się bezpośrednio w „Solidarność” bądź z nią otwarcie sympatyzujący.

Zachodząca w PAX ewolucja ideowo-polityczna znalazła także swój wydźwięk podczas tradycyjnych, cyklicznych obchodów rocznicy rewolucji październikowej, która 6 listopada 1980 r odbyła się w auli Liceum im Św. Augustyna. Niemal od początku istnienia Polski Ludowej było to jedno z najważniejszych świąt wpisanych do „komunistycznego kalendarza”, a zarazem strzeżonych przez partię dogmatów, mówiących o tym, że sojusz polsko-radziecki stanowi gwarancję nienaruszalności granic i bezpieczeństwa państwa. Po sierpniu 1980 r. starano się jednak ów dogmat wykorzystywać do otwartego zwalczania „Solidarności”, która miała zagrażać tym doktrynalnym fundamentom. 6 listopada PAX już tradycyjnie zorganizował środowiskowe obchody rocznicowe pod szyldem: „Cały naród bazą polsko-radzieckiego sojuszu”. Podczas specjalnie zorganizowanej akademii (połączonej z konferencją) uspakajano, że działalność związków zawodowych nie zagraża porządkowi społecznemu i sojuszowi z Moskwą, a wręcz przeciwnie, umacnia autentyczne więzi z „narodem słowiańskim”, także poprzez wewnętrzne działania zmierzające do poprawy sytuacji w kraju, dialog i poszukiwanie kompromisu. W ten sposób nie tylko partia - dotychczas strażnik sojuszu, ale cały naród miały umacniać wzajemne relacje, w duchu podmiotowości oraz zrozumienia potrzeb i aspiracji narodowych. R. Reiff w swoim referacie stwierdzał: „Łącznikiem sojuszu polsko-radzieckiego nie może być tylko marksizm zawężony do filozofii marksistowskiej. Sojusz to sprawa większa, jeśli jej adresatem ma być cały naród, to nie do pomięcia są wartości humanizmu chrześcijańskiego, tak istotne dla tożsamości narodowej” ${ }^{36}$. Jeszcze bardziej dosadnie ujął to Wiktor Szwechowicz - szef COSK: „Jeśli fundamentem sojuszu ma być cały naród, to również bazą rządzenia w Polsce powinien być cały naród, a nie jego część” („Słowo Powszechne”, 10 XI 1980, nr 243, s. 2). „Odnowa” moralna nie mogła się dokonać tylko i wyłącznie pod partyjne dyktando, ale ruchy oddolne, demokratyczne i samorządne, „w duchu samostanowienia i suwerenności”, nie kwestionując jednak imponderabiliów ustrojowych Polski Ludowej”.

${ }^{36}$ Prasa stowarzyszenia zamieściła obszerną relację z tych rocznicowych obchodów. Por. (7-9 XI 1980). „Słowo Powszechne”, nr 242, s. 1; (10 XI 1980). „Słowo Powszechne”, nr 243, s. 1; R. Reiff (10 XI 1980, s. 2). Także: (16 XI 1980). „Kierunki”, nr 46, s. 2 oraz (16 XI 1980). „Kierunki”, nr 46, s. 3-4. 
W tym samym dniu, to jest 6 listopada 1980 r. zebrał się także zarząd PAX, na którym R. Reiff w programowym referacie pt. „Demokracja polska” zwrócił przede wszystkim uwagę na perspektywy rozwojowe kraju („Słowo Powszechne”, 10 XI 1980, nr 243, s. 1-2). Reiff rozpoczął od przypomnienia polskich wielowiekowych źródeł demokracji i tolerancji wyznaniowej, tłumionych przez egoizm grup społecznych i wybujałą wolność, graniczącą z anarchizmem. Głównym schorzeniem narodowej psychiki miał być brak umiejętności przełamania antynomii między silną władzą a poczuciem własnej, niczym nieskrępowanej wolności. Współcześnie, zdaniem Reiffa, ten dylemat ponownie stał się aktualny. W szeregu zaprezentowanych w tym referacie tez, kilka zwraca szczególną uwagę. Utrata przez PZPR społecznego zaufania była faktem bezspornym. Rządząca partia przez cały okres powojenny nie potrafiła przełożyć teoretycznych założeń socjalizmu na polityczną praktykę. Wskutek tego naród, zmuszony do bezkrytycznego podporządkowania woli władz, został pozbawiony wszelkich form samorządności i inicjatywy. Społeczeństwo zostało zatomizowane i strukturalnie rozbite. W związku $\mathrm{z}$ tym naczelnym problemem polskiej polityki była „demokracja”, a właściwie jej deficyt. Należało więc przede wszystkim przełamać fatum w postaci układu, jaki w latach siedemdziesiątych wytworzył się na linii: partia - społeczna diaspora. Partia całkowicie zmonopolizowała życie społeczne, ograniczając do minimum podmiotowość obywateli, co musiało prowadzić najpierw do frustracji, a następnie do eksplozji narodowego niezadowolenia. Strajkującym w sierpniu 1980 r. nie chodziło jednak o krytykę socjalizmu jako systemu, ale o krytykę „niewydolności” i popełnionych przez partię błędów. Narosło więc wiele „niespójności”, które Reiff odczytywał w kilku wymiarach: 1) luce pokoleniowej w aparacie władzy; 2) luce między wychowaniem partii a wychowaniem w produkcji (nadużywanie języka ideologicznego w komunikacji z robotnikami, fikcja reżimowych związków zawodowych); 3) luce między rządzącymi a rządzonymi (hamowanie samorządności i inicjatywy oddolnej, społeczna atomizacja, brak czynnika społecznej kontroli, ignorancja władzy wobec społecznych oczekiwań i aspiracji); 4) luce między warunkami życia wykonawców a przywilejem rozkazodawców (anomia społeczna, pojawienie się „partyjnej arystokracji, stratyfikacja społeczna, nonszalancja władz w sprawach szeroko rozumianej polityki społecznej); 5) luce między aspiracjami dostatniego życia człowieka pracy a ambicjami człowieka władzy (nieudolna i preparowana polityka komunikacyjna władz ze społeczeństwem, dyletanctwo i „bizantynizm”) (R. Reiff, 15-16 XI 1980, s. 3-5; Idem, 23 XI 1980, s. 3, 6-7). W oparciu o tę diagnozę należało w opinii przewodniczącego PAX wypracować nową formułę 
współdziałania „różnych sił” w ramach systemu politycznego. Najpierw jasno określić stanowisko partii wobec takich problemów jak: przebudowa struktury państwowej, przywrócenie znaczenia ciałom przedstawicielskim, odbudowa polskiej samorządności, autonomia dla rodziny i integralność osoby ludzkiej, zrozumienie przez elity rządzące, że formuła partii jako siły przewodniej nie jest sprawą samej partii, ale narodu jako wieloświatopoglądowej wspólnoty. Proces przebudowy życia społeczno-politycznego zakładał następnie zorganizowanie aparatu społecznej, oddolnej kontroli „stojącej na zewnątrz władzy” i dysponującej prawem obywatelskiego veta. A zatem program Reiffa oznaczał całkowite odejście od lansowanej przez ponad 35 lat przez Piaseckiego idei państwa, w którym to zachodzić miały wszelkie procesy społeczne i polityczne. Podobnie do problemu podchodziła wykładnia marksizmu i leninizmu oraz praktyka polityczna PRL. Teraz według Reiffa nadszedł dogodny moment, aby uczynić system bardziej pluralistycznym, oddać część uprawnień i funkcji państwa w ręce autentycznego i niezależnego aparatu samorządowego („,zewnętrzna siła samorządowa") z przypisanymi mu zadaniami kontrolnymi ${ }^{37}$.

Podstawowe tezy wyrażone w referacie programowym uzupełni Reiff podczas przemówienia w Sejmie 21 listopada 1980 r. Ponownie skrytykował działania ekipy rządzącej, nieufność partii wobec nowych związków zawodowych oraz działalność fasadowej Komisji ds. Reformy Gospodarczej, obsadzonej według klucza partyjnego, bez uwzględnienia siły, jaką jest „Solidarność”, a także innych środowisk opiniotwórczych i eksperckich. Na koniec powiedział: „(...) mówiąc naród, myślimy, również - NSZZ „Solidarność”. Stanowi ona przecież integralną, znaczną, liczącą się część narodu" ${ }^{38}$. Powtórzył to jeszcze raz w rozwiniętej formie na ostatnim w 1980 r. zebraniu zarządu PAX (25 XI 1980). Miało to być zamyśle spotkanie jubileuszowe, zorganizowane w 35-lecie postępowego ruchu katolików świeckich (od ukazania się pierwszego numeru tygodnika

37 Zob. również: (15-16 XI 1980) „Słowo Powszechne”, nr 248, s. 1; (21-23 XI 1980) „Słowo Powszechne", nr 253, s. 1. Zaprezentowany przez R. Reiffa na zebraniu zarządu Stowarzyszenia PAX (6 XI 1980 r.) referat programowy, pomimo, że został przyjęty za dokument całego ruchu, spotkał się z krytyką niektórych działaczy, którzy od dawna byli jego oponentami i twardo stali na gruncie myślenia państwowego. Ich głos publikowała prasa stowarzyszenia, co świadczyło o otwartości i pluralizmie poglądów w PAX. Zob. np. Z. Czajkowski (24 XI 1980, s. 1); J. Stefanowicz (25 XI 1980, s. 1); Z. Czajkowski (26 I 1981, s. 3-4); W. Lewandowski (20-22 II 1981, s. 3); (30 IX 1980) „Kierunki”, nr 48, s. 3; S. Wlazło (19 IV 1981, s. 3); A. Radajewski (5 VII 1981, s. 1, 3); J. Wagner (5 VII 1981, s. 3, 6); J. Wołkowski (12 VII 1981, s. 3); A. Bocheński (6 IX 1981, s. 1, 3).

38 Cały tekst przemówienia zamieściło „Słowo Powszechne”. Por. (24 XI 1980) „Słowo Powszechne”, nr 254, s. 2. 
„Dziś i Jutro”) ${ }^{39}$, ale tym razem obchodzone skromnie, bez pompy celebry, obecności władz państwowych i partyjnych, dyplomatów radzieckich, także bez nużących ideologicznych referatów, które towarzyszyły tego typu uroczystościom $\mathrm{w}$ przeszłości ${ }^{40}$. Najważniejszym dokumentem wówczas przyjętym był list (apel) kierownictwa stowarzyszenia do członków i kandydatów, w którym w sposób syntetyczny zarysowano ideową drogę środowiska, od czasów „ruchu nienazwanego”, po „ruch odnowy”. Ponownie poddano surowej krytyce działalność PZPR w poprzedniej dekadzie, tym razem jednak wymieniając sprawców kryzysu państwa z imienia i nazwiska. Wzywano ekipę rządzącą do roztropności i rozwagi, przestrzegając przez siłami konserwatywnymi, które metodami siłowymi chciałyby ujarzmić oddolny proces samoorganizacji społeczeństwa. Wysuwano wcześniej artykułowane postulaty demokratyzacji, budowy samorządnego społeczeństwa obywatelskiego, ale poparcie dla „Solidarności”, zadeklarowane już wcześniej, kilkakrotnie i wprost nie było bezwarunkowe. Autorzy listu mieli świadomość, że „Solidarność" nie stanowi pod względem ideowym „monolitu”, że tworzą ją ludzie o różnym doświadczeniu, ideowym zakorzenieniu, sięgający do różnych tradycji szkół politycznego myślenia. W związku ścierały się dwie główne orientacje: „fundamentalistów” i „pragmatyków” - pisano. Największe niebezpieczeństwo dostrzegano wśród byłych członków KSS KOR, którzy od jesieni 1980 r. zasilili zaplecze eksperckie związku, tak na szczeblu centralnym, jak i w strukturach regionalnych i zakładowych. Kwestionowali oni podstawy ustrojowe Polski Ludowej, uciekali się do haseł strajku generalnego, który mógł sprowokować partię do siłowych rozwiązań i konfrontacji, niwecząc dzieło „porozumień sierpniowych”. Wówczas za ten dramatyczny scenariusz winę ponosiłyby dwie strony konfliktu, choć w różnym stopniu. Co najistotniejsze jednak, kierownictwo PAX dostrzegało w „Solidarności” nie tyle typowy związek zawodowy walczący o prawa pracownicze i socjalne, ile społeczny ruch rewindykacji społecznych i obywatelskich o religijnej tożsamości, ubiegający się o upodmiotowienie narodu. W liście czytamy między innymi: „Solidarność będąca ruchem o znacznym udziale przedstawicieli klasy robotniczej, nie odwołuje się do tradycji międzynarodowego ruchu robotniczego. Nie posługuje się też tradycyjną symboliką proletariacką, a nawiązuje głównie do symboliki, tradycji

39 Cały numer „Słowa Powszechnego” (255) z 25 XI 1980 poświęcono obchodom 35-lecia Stowarzyszenia PAX.

40 Prasa Stowarzyszenia PAX od czerwca 1980 do marca 1981 r. zamieszczała rozliczne teksty przypominające dorobek, tradycję i wielowymiarową działalność Stowarzyszenia PAX w ramach cyklu „PAX - 35 lat”. 
oraz retoryki narodowej i katolickiej. Pieśnią intonowaną na jej zgromadzeniach nie jest Międzynarodówka, a z reguły „Jeszcze Polska nie zginęła” lub „Boże coś Polskę”. Nie używa się też w zasadzie czerwonego sztandaru, ale biało-czerwony. Działacze „Solidarności” posługują się często symbolem krzyża, a niektórzy wręcz demonstrują swoją religijność (Lech Wałęsa, Kazimierz Świtoń, Anna Walentynowicz). Dla wielu działaczy „Solidarności” charakterystyczny jest stereotyp „Polaka - katolika”"11.

Grudzień 1980 r. zamykał pierwszy „posierpniowy” etap ewolucji ideowo-politycznej Stowarzyszenia PAX. Wystąpienia programowe i publicystyczne członków środowiska oraz deklarowane i faktyczne, choć nie bezwarunkowe poparcie udzielone „Solidarności” sprawiły, że PAX powoli odzyskiwał wiarygodność społeczną. Stowarzyszenie nie było już tylko bezkrytycznym i serwilistycznym sojusznikiem partii, ale jako konstruktywny ruch katolików świeckich uzyskiwało podmiotowość w relacjach z aparatem partyjno-rządowym. Patrząc z perspektywy ideowej, można stwierdzić, że wstrząsnęła nim „rewolucja”. Nie był to już bowiem ruch, który tworzył i przez 35 lat rozwijał B. Piasecki ${ }^{42}$.Zmieniło

41 Zob. (28 XI 1980) „Słowo Powszechne”, nr 257, s. 1-2; (28 XI 1980) „Słowo Powszechne”, nr 257, s. 1. Również: (7 XII 1980) „Kierunki”, nr 49, s. 1-2. Tezy zawarte w art. Reiffa rozwinął Jan Król (4 I 1981, s 3).

42 O ile jeszcze w styczniu 1980 r. prasa stowarzyszenia w rocznicę śmierci B. Piaseckiego starała się przypomnieć jego sylwetkę i myśl polityczną (np. J. Wójcik (6 I 1980, s. 1, 6), o tyle już rok później niemal całkowicie ją przemilczano, poza krótkim tekstem S. Wlazło (4 I 1981, s. 3). Znamienny wydaje się fakt, że w otwierającym w 1981 r. numerze „Słowa Powszechnego”, w rocznicę śmierci B. Piaseckiego, nie zamieszczono żadnego artykułu wspomnieniowego, a jedynie dwa nekrologi: rodziny i zarządu PAX-u. Z kolei w maju 1981 r. kierownictwo PAX-u na wniosek Reiffa, na posiedzeniu zarządu stowarzyszenia przyjęło komunikat, w którym mowa była o wstrzymaniu dalszego kolportażu książki B. Piaseckiego pt. Kierunki. Czytamy tam m.in.: „Szereg zawartych w tym zbiorze publikacji nie wyraża aktualnych ocen ideowo-politycznych ruchu”. Zob. (13 V 1981) „Słowo Powszechne”, nr 95, s. 1. Autorami dokumentu byli: Wrzeszcz, Lewandowski i Kabat. Na posiedzeniu zarządu Stowarzyszenia PAX 5 VI 1981 r. aprobowano w trybie uchwały komunikat, jako oficjalne stanowisko ruchu. Szeroko na temat dyskusji wokół wstrzymania kolportażu książki Piaseckiego pisze J. Skwarski (1990, s. 127-129). Kolejną ważną kwestią, która świadczyła o krytycznej ocenie powojennego dziedzictwa PAX-u, była dyskusja nad nową wykładnią „Wytycznych”. Sprawa ta została zasygnalizowana w komunikacie z 6 maja, następnie dyskutowano nad nią od czerwca 1981 r. Dokument miał zostać przyjęty podczas obrad zarządu 25 XI 1981 r. - w 35 rocznicę powstania środowiska „Dziś i Jutro”. Okazało się jednak, że część działaczy chciało odstąpić od przyjmowania „Wytycznych” i domagała się przygotowania projektu „Deklaracji Ideowej”. W efekcie powstała deklaracja daleko odbiegająca od ideologii PAX-u, rewidująca tezę o socjalistycznym zaangażowaniu w państwo o wieloświatopoglądowej strukturze, wyrażano potrzebę samorządności i demokratyzacji w ramach istniejącego systemu politycznego, poszerzenia bazy rządzenia i koncepcję narodu jako podstawy sojuszu polsko-radzieckiego. Pomimo że deklaracja wywołała podczas spotkania zarządu 4 XI 1981 r. opór wśród 
się również zasadniczo oblicze prasy PAX-u, nie tylko dlatego, że ingerencja cenzury nie była już tak silna, ale przede wszystkich dlatego, że czasopisma otwarły się na problemy jeśli nie nowe, to trudne, jak samorządność i demokratyzację. W ruchu postępowych katolików doszło również do wymiany pokoleniowej. Dawni, starzy działacze, związani z PAX-em, od początku jego istnienia utracili swoją pozycję i znaczenie. Na ich miejsce przychodzili młodzi sympatycy (także członkowie) „Solidarności”, którzy awansowali nie tylko w centrali, ale również w strukturach terenowych.

W wysuwanych wówczas przez stowarzyszenie postulatach (referatach programowych) opowiadano się przede wszystkim za realizacją porozumień sierpniowych i wrześniowych, dialogiem, współdziałaniem i „odnową społeczną”. Krytykowano wszelkie próby „siłowego” rozwiązania kryzysu. PZPR przestrzegano przed „konfrontacją” z masowym ruchem rewindykacji społecznej, „Solidarność" przed strajkami, które zaostrzały pole konfliktu i rozbijały jedność narodu. Proponowano odbudowę samorządności (związkowej, rolniczej43 i akademicko-studenckiej), przywrócenie właściwej roli ciałom przedstawicielskim. Partia - jak wówczas przekonywano - utraciła mandat do tego, aby określać się jako „siła przewodnia narodu”, bazą rządzenia był cały naród, a nie tylko jego część. Otwarcie domagano się „poszerzenia bazy rządzenia”. Co oznaczało, że samorządne związki zawodowe oraz niezależne organizacje środowiskowe mogłyby tworzyć nową „oś pionową” struktur państwowych. Koncepcja ta - kluczowa dla programu PAX-u była konsekwentnie rozwijana do 13 grudnia $1981 \mathrm{r}$. (R. Reiff (25 X 1981, s. 1-3) $)^{44}$. Swój najpełniejszy wyraz znalazła w obszernym

części działaczy PAX-u i decyzję o jej przyjęciu odłożono w czasie. Ostatecznie nie została przyjęta, ponieważ 13 XII 1981 r. wprowadzono stan wojenny i działalność PAX-u zawieszono. Fragmenty dyskusji nad dziedzictwem PAX-u na okoliczność 35-lecia ruchu zamieściły „Kierunki”. Por. (7 XII 1981). „Kierunki”, nr 49, s. 6-7.

43 Już od września 1980 r. poświęcano temu zagadnieniu na łamach prasy stowarzyszenia sporo miejsca. Zob. np. (mos.) (18 IX 1980, s. 1); L. Stelmaszczyk (21 X 1980, s. 3); K. Piecha, L. Stelmaszczyk (10 XI 1980, s. 3); E. Majkut (13 XI 1980, s. 3); (j.ś.) [J. Ślaski]. (20 XI 1980, s. 1); (mos.) (8-10 V 1980, s. 1); (14 V 1981) „Słowo Powszechne”, nr 96, s. 1; (14 V 1981) „Słowo Powszechne”, nr 96, s. 2; (29 III 1981) „Kierunki”, nr 12, s. 1, 8; A.W. Kaczorowski, J. Mach, M. Machnacki (24 V 1981, s. 11). W 1981 r. Reiff zaangażował się w rejestrację NSZZ „Solidarność” Rolników Indywidualnych. Spotykał się z regionalnymi działaczami wiejskiej samorządności, zabiegał o rejestrację w Sejmie i Radzie Państwa. Również prasa stowarzyszenia pisała o działalności związkowców na wsi. W artykule pt. „Rolnik ma rację” twierdził wprost, że chciałby być „ambasadorem tej sprawy” Por. (10 V 1981) „Kierunki”, nr 19, s. 7. Por. także: R. Reiff (1988), s. 172-206.

44 Do czasu opublikowania głośnego artykułu pt. „Wielka Koalicja” koncepcja „poszerzenia bazy rządzenia” przybierała różne formy, np.: Narodowej Rady Samorządowej, Izby Samorządowej (druga 
artykule R. Reiffa pt. „Wielka Koalicja”, w którym pisał wprost, że „linia porozumienia” powinna być poprzez budowę współdziałania „wielkiego centrum”: Kościoła, PZPR i NZSS „Solidarności” ${ }^{45}$.W istocie oznaczało to utratę faktycznego monopolu przez rządzącą partię ${ }^{46}$.W sferze ideowej - jak tłumaczono - realizację idei „socjalizmu całego narodu”. Ideowo-programowy „zwrot” PAX-u, generalnie życzliwie odbierany przez „konstruktywną opozycję” (także niektórych liberałów partyjnych), miał też swoich krytyków. Niektórzy, jak choćby Mieczysław F. Rakowski (też utożsamiany ze skrzydłem liberalnym w PZPR), przypisywał kierownictwu stowarzyszenia intencje daleko szersze, zmierzające do budowy „ośrodka chadeckiego”, który w dogodnym momencie miałby się przerodzić w stronnictwo polityczne ${ }^{47}$. Konserwatywne skrzydło PZPR szło jeszcze dalej, sugerując, że PAX jest katolicką przybudówką „,solidarnościowej ekstremy”, a jej

izba parlamentu), Ruchu Porozumienia Narodowego, czy Komitetu Ocalenia Narodowego. Wspominano o niej w wielu artykułach już od lutego 1981 r. Zob. np. (22 II 1981) „Kierunki”, nr 8, s. 1, 5-6; (22 II 1981) „Kierunki”, nr 12 s. 2-3; (17-19 VII 1981) „Słowo Powszechne”, nr 144, s. 3; R. Reiff (6 IX 1981, s. 2); R. Reiff (4 XI 1981, s. 2); (11 X 1981) „Kierunki”, nr 41, s 2; R. Reiff (10 VI 1981, s. 5-6); R. Reiff (1 XI 1981, s. 1-3). Zob. też rozwinięcie koncepcji „wielkiej koalicji: (28 X 1981) „Kierunki”, nr 45, s. 1, 3; R. Reiff ( 8 XI 1981, s. 1, 3); R. Reiff (22 XI 1981, s. 1-2); R. Reiff (7 XII 1981, s. 1-2); R. Reiff (13 XII 1981, s. 1-2).

45 Druk artykułu poprzedziło sejmowe przemówienie Reiffa z 25 XI, w którym zarysował główne założenia swojej koncepcji. Później dokonywano jej wykładni i oceny jeszcze wielokrotnie, w kolejnych referatach programowych, tekstach publicystycznych, wypowiedziach publicznych (na spotkaniach aktywu PAX, w centrali i w terenie, w radio i telewizji), w licznych wywiadach prasowych (także w prasie bezdebitowej), udzielanych głównie przez przewodniczącego Stowarzyszenia PAX. Por. Skwarski (1990, s. 136-151); R. Reiff (1988, s. 276-387); R. Reiff (2005, s. 159-160); Pilecki (1986, s. 37 - 62); Burdeński (1988, s. 17-19); J. Huk (1984, s. 59-68); J. Kuciński. (1988, s. 103-109).

46 Co ciekawe, koncepcja „Wielkiej Koalicji” była w swojej treści bliźniaczo podobna do postulatów wysuniętych przez Konserwatorium „Doświadczenia i Przyszłość”, w opracowanym na przełomie wiosny i lata 1980 r. raporcie. Zob. (1980). Doświadczenie i przyszłość. Ocena sytuacji w Polsce i prognoza rozwoju wydarzeń na dzień 10 lipca 1981 roku, Warszawa: na prawach maszynopisu. W nieco zmodyfikowanej formie podobny program wysuwało opozycyjne środowisko „Głosu” (Antoni Macierewicz, Ludwik Dorn, Jakub Karpiński, Jarosław Kaczyński i inni), tyle tylko, że już po wprowadzeniu stanu wojennego. Wychodziło ono z założenia, że po wprowadzeniu stanu wojennego państwo partyjne przestało istnieć, a jedynymi trwałymi instytucjami są: Kościół, wojsko i społeczeństwo. Por. T. Sikorski (2009, s. 201-224); T. Sikorski (2010, s. 91-101).

47 Pogląd taki wyraził M.F. Rakowski 14 XI 1980 r. podczas spotkania z aktywem partyjnym w Zielonej Górze. Por. Skwarski (1990, s. 112); Dworaczek (2014, s. 293). Podobnie działania kierownictwa PAX-u oceniał Wiesław Mysłek, profesor Wyższej Szkoły Nauk Społecznych przy KC PZPR. Por. W. Mysłek (1982). Faktyczne próby przygotowania zaplecza do odbudowy krajowego ruchu chadeckiego podejmowali wówczas: Janusz Zabłocki z PZKS oraz seniorzy Stronnictwa Pracy (Kazimierz Studentowicz, Konstanty Turowski, Stefan Kaczorowski, Władysław Siła-Nowicki i Zbigniew Madeyski). Zwrócili się oni 23 września 1981 r. ze specjalnym memoriałem do Episkopatu 
lider - R. Reiff, karierowiczem i „zaślepionym oportunistą” rozbijającym system polityczny Polski Ludowej, wykorzystującym do tego miejsce i pozycję, jaką PAX zajmował przez ponad trzydzieści lat ${ }^{48}$. Z drugiej jednak strony, przynajmniej w pierwszych miesiącach 1981 r., kiedy kraj ponownie ogarnęła fala strajków, władze czyniły wobec stowarzyszenia różne pojednawcze gesty. W „terenie” lokalni dygnitarze partyjni chętnie przyjmowali członków stowarzyszenia, wzrosła również ich pozycja działaczy PAX-u w radach narodowych. Otworzyły się też drogi awansu na szczeblu wojewódzkim. PAX miał się bowiem stać oparciem dla rządzącej partii, sojusznikiem w poszukiwaniu porozumienia $\mathrm{z}$ „Solidarnością”. Uwieńczeniem tego procesu był wybór R. Reiffa do Rady Państwa (12 II 1981 r.).

W konsekwencji wprowadzenia stanu wojennego (uchwałą Rady Państwa z 12 XII 1981 r., na wniosek Wojskowej Rady Ocalenia Narodowego) 13 grudnia 1981 r. działalność PAX-u, podobniej, jak innych stowarzyszeń katolickich, zawieszono. Ryszard Reiff na posiedzeniu Rady Państwa jako jedyny z czternastu jej członków sprzeciwił się zatwierdzeniu uchwały o wprowadzeniu stanu wojennego i dekretu o stanie wojennym, za co został wkrótce odwołany ${ }^{49} .23$ stycznia 1982 r., podczas zebrania zarządu Stowarzyszenia PAX, Reiff został także odwołany z funkcji przewodniczącego. Jego miejsce zajął Zenon Komen-

w sprawie reaktywacji Stronnictwa Pracy. Indywidualne próby reaktywacji „ośrodka chadeckiego” podejmował również kilka razy Studentowicz.

48 Partyjni konserwatyści, określani w ówczesnym żargonie jako „beton partyjny”, skupiali się wokół rożnych organizacji i klubów, m.in.: Zjednoczenia Patriotycznego „Grunwald”, Klubu „Warszawa 1980", Katowickiego Forum Partyjnego i Forum Dyskusyjnego Komunistów Warszawy, Dyskusyjnego Klubu Inteligencji Partyjnej. Z tymi środowiskami związani byli prominentni działacze PZPR, np. Tadeusz Grabski, Stefan Olszowski, Albin Siwak i Andrzej Żabiński. Dysponowały one również własnymi ogólnopolskimi tytułami prasowymi, np. „Płomienie”, „Barwy” i „Rzeczywistość”. Zob. też: J. Kazimierski (2013, s. 209-232); P. Gasztold-Sen (2012). Do najbardziej napastliwych ataków na Stowarzyszenie PAX i personalnie R. Reiffa należały teksty: (4 X 1981) „Rzeczywistość”, nr 20, s. 4; P. Znamieniecki (4 X 1981, s. 1, 4); (25 X 1981) „Rzeczywistość”, nr 23, s. 4; J. Górecki (5 XI 1981, s. 4 (zob. też odpowiedź „Słowa Powszechnego” - J. Ślaski (9 XI 1981, s. 2); (8 XI 1981) „Rzeczywistość”, nr 25, s. 4; P. Znamieniecki (15 XI 1981, s. 1, 4); H. Wandowski (22 XI 1981, s. 3, 10); (22 XI 1981) „Rzeczywistość”, nr 27, s. 4; J. Górecki (6 XII 1981, s. 1,4); (6 XII 1981) „Rzeczywistość”, nr 29, s. 3; N. Michta (6 XII 1981, s. 5); F.L. (23 X 1981, s. 2); (26 XI 1981) „Trybuna Ludu”, nr 278, s. 3. Koncepcję „wielkiej koalicji” atakowano również w trakcie wystąpień publicznych, np. podczas narady Stefana Olszowskiego z aktywem partyjnym w Ostrowcu Świętokrzyskim, podczas spotkania Olszowskiego z zespołem redakcji „Sztandaru Młodych”, podczas przemówienia Mariana Orzechowskiego na posiedzeniu wszechnicy partyjnej w Poznaniu.

49 Z.M. Przetakiewicz jr twierdził, że już 24 XII 1981 r. Reiff przesłał gen. W. Jaruzelskiemu prywatny list, w którym składał mu podziękowania i życzył powodzenia. Por. Z.M. Przetakiewicz jr (2016, s. 125). 
der, reprezentant orientacji „zachowawczej”. Do podobnych roszad („czystek”) wkrótce doszło również w strukturach terenowych (na wszystkich szczeblach) stowarzyszenia.

BiBLIOGRAFIA:

Archiwa:

AIPN Bu 0639/21 t. 1-3.

AIPN Bu 00170/286/ t. 1-7.

AIPN Bu 0259/6.

Pamiętniki, wspomnienia, relacje wywiady:

(11-12 X 1980). Czujmy się gospodarzami - ponośmy odpowiedzialność za kraj. Rozmawiamy z Bogdanem Lisem i Lechem Bądkowskim. Słowo Powszechne, 221, 1-2.

(26 XI 1981). Porozumienie czy konfrontacja?. Rozmowa ze Stefanem Olszowskim, członkiem Biura Politycznego KC PZPR. Trybuna Ludu, 278, 3.

Dobraczyński, J. (1977). Tylko w jednym życiu. Warszawa: wyd. IW PAX.

Kętrzyński, W. (1967). Na przełomie 1944-1945. Więź, 11-12, 154-170.

Przetakiewicz, Z.M. jr. (2016). Spowiedź grzesznika. Z PAX-u, Solidarności i Andersena. Łomianki: wyd. LTW.

Reiff, R. (1988). Czas Solidarności. Warszawa: wyd. Wola.

Reiff, R. (1993). Gra o życie. Warszawa: wyd. Unicorn.

Siedziako, M. (2009). Zrobiliśmy to po naszemu. Rozmowa z Andrzejem Kotulą. Sedina. pl magazyn. Rocznik Miłośników Dawnego Szczecina, 4, 106-113.

Skwarski, R. (1990). Za zielona kurtyną. PAX lat 1975-1982. Londyn: wyd. Polskiej Fundacji Kulturalnej.

Szeremietiew, R. (1993). W prawo marsz. Warszawa: wyd. PRINT.

Wójcik, J. (2013). Dzienniki (1976-1977). Archiwum Narodowej Demokracji, 1, 226-285.

Wójcik, J. (2017). Śmierć Bolesława Piaseckiego. Myśl Polska, 3-4.

Publicystyka polityczna, dokumenty drukowane:

(1 IX 1980). Odpowiedzialność - obowiązki - prawa w życiu narodu. Słowo Powszechne, $188,1,3$.

(10 V 1981). Rolnik ma rację (dyskusja redakcyjna). Kierunki, 19, 7.

(10 X 1980). Parlamentarna kontrola rządu. Przemówienie posła Jana Waleczka - Koło PAX. Słowo Powszechne, 220, 5.

(10 X 1980). Studenci w nurcie odnowy. Słowo Powszechne, 220, 1.

(10 X 1980). Wspólnie pracować - sprawiedliwie dzielić. Słowo Powszechne, 220, 6.

(10 XI 1980). Posiedzenie Zarządu Stowarzyszenia PAX. Słowo Powszechne, 243, 1-2.

(10 XI 1980). R. Reiff. Cały naród bazą sojuszu polsko-radzieckiego. Słowo Powszechne, $243,2$. 
(10 XI 1980). W Stow. PAX w rocznicę Rewolucji Październikowej. Cały naród bazą sojuszu polsko-radzieckiego. Słowo Powszechne, 243, 1.

(11 III 1979). Posiedzenie Zarządu Stowarzyszenia PAX. Kierunki, 10, 2.

(11 X 1981). Uchwała Zarządu Stow. PAX. Kierunki, 41, 2.

(12 X 1980). O nowy kształt uczelni. Kierunki, 41, 1, 5.

(13 IV 1980). O krytyczną kontynuację ustroju i władzy. Przemówienie sejmowe posła R. Reiffa (Koło PAX). Kierunki, 10, 1-2.

(13 V 1981). Komunikat dotyczący książki B. Piaseckiego. Kierunki. Słowo Powszechne, $95,1$.

(13 X 1980). Spotkałem się z robotnikiem... Dyskusja młodych. Słowo Powszechne, 222, 5-6.

(14 I 1979). Ostatni hołd Bolesławowi Piaseckiemu. Kierunki, 2, 1-2.

(14 IX 1980). Wystąpienie R. Reiffa na Zarządzie Stow. PAX w dniu 4 IX 1980 r. Kierunki, 37, 1-2.

(14 V 1981). Na tę chwilę czekali chłopi 36 lat. Słowo Powszechne, 96, 2.

(14 V 1981). NSZZ RI „Solidarność” zarejestrowany. Słowo Powszechne, 96, 1.

(15-16 XI 1980). Jedyna droga. Słowo Powszechne, 248, 1.

(15 III 1981). Uczelnie po strajkach. Kierunki, 11, 1, 4.

(15 VI 1980). Posiedzenie Zarządu Stow. PAX. Kierunki, 24, 1.

(15 VI 1980). Walne Zgromadzenie Stow. PAX. Kierunki, 24, 2.

(15 X 1980). Studencki dylemat. Słowo Powszechne, 224, 1-2.

(16 XI 1980). Łączyć potrzeby społeczne z wyrazami racji stanu. Kierunki, 46, 3-4.

(17-19 VII 1981). Front Porozumienia Narodowego. Sonda „Słowa Powszechnego”. Słowo Powszechne, 144, 3.

(17 IX 1980). Posiedzenie Zarządu Stowarzyszenia PAX. Słowo Powszechne, 201, 1.

(18-19 X 1980). Linia działania. Dwa przemówienia Ryszarda Reiffa podsumowujące dyskusję na posiedzeniach Zarządu Stowarzyszenia PAX w dniach 4 i 5 września br. Słowo Powszechne, 227, 3-4.

(18-19 X 1980). Posiedzenie Zarządu Stowarzyszenia PAX w dniu 4 września 1980 roku. Fragmentu dyskusji. Słowo Powszechne, 227, 1, 4.

(18 VIII 1980). Musimy wspólnie stawić czoła wyzwaniu chwili. Przemówienie prezesa Rady Ministrów Edwarda Babiucha przed kamerami Telewizji Polskiej. Słowo Powszechne, 178, 1.

(19-21 X 1980). Linia porozumienia. Referat Ryszarda Reiffa wygłoszony na posiedzeniu Zarządu Stowarzyszenia PAX w dniu 15 IX 1989. Słowo Powszechne, 203, 3-4.

(19 II 1981). Niezależne Zrzeszenie Studentów Zarejestrowane. Słowo Powszechne, 35, $1-2$.

Łuczyńsk, R. (19 II 1981). NZS: Przywrócić aktywność studencką. Słowo Powszechne, 35,3 .

(19 XI 1980). Spotkanie Przewodniczącego Stowarzyszenia PAX Ryszarda Reiffa z młodzieżą. Młodzi wobec aktualnej sytuacji społeczno-politycznej. Słowo Powszechne, 251,3 . 
(1978). Wywiad z Romualdem Szeremietiewem. Czego pragną młodzi z PAX-u?. Droga, 3.

(1984). PAX w cieniu wielkiej polityki. Droga, 6.

(2 IX 1980). Strajk na Wybrzeżu zakończony. Podpisano porozumienie między komisjami rządowymi a MKS w Szczecinie i Gdańsku. Słowo Powszechne, 189, 1-2.

(2 X 1980). Posiedzenie Zarządu Oddziału Wojewódzkiego Stowarzyszenia PAX w Krakowie z udziałem Ryszarda Reiffa. Słowo Powszechne, 213, 2.

(2 XI 1980). Posiedzenie Zarządu Stow. PAX. Oświadczenie R. Reiffa. Kierunki, 44, 2.

(20 VIII 1980). Niezbędny jest wewnętrzy spokój i odpowiedzialność za losy Ojczyzny. Przemówienie radiowo-telewizyjne I sekretarza KC PZPR Edwarda Gierka. Słowo Powszechne, 180, 1-2.

(20 VIII 1980). Uroczystości z udziałem Prymasa Polski. Słowo Powszechne, 180, 1-2.

(20 X 1980). Linia działania. Z dyskusji Zarządu Stowarzyszenia PAX. Słowo Powszechne, $228,3-4$.

(21-23 XI 1980). Lata dialogu. Słowo Powszechne, 253, 1.

(21 I 1979). Posiedzenie Zarządu Stowarzyszenia PAX. Przewodniczącym Zarządu Ryszard Reiff. Kierunki, 3, 2.

(21 X 1979). Posiedzenie Zarządu Stowarzyszenia PAX. Postawa narodu - czynnikiem decydującym o skali i tempie rozwoju Polski. Kierunki, 42, 2.

(22 II 1981). Struktura porozumienia. Kierunki, 8, 1, 5-6.

(22 II 1981). Wymogi aktualnej sytuacji. Referat Prezydium i Koła Stow. PAX wygłoszony na posiedzeniu Zarządu Stow. PAX w dn. 9 III br. Kierunki, 12, 2-3.

(22 X 1980). Oświadczenie Ryszarda Reiffa. Słowo Powszechne, 230, 1-2.

(22 X 1980). Posiedzenie Zarządu PAX. Słowo Powszechne, 230, 1.

(22 XI 1981). Front nadziei. Rzeczywistość, 27, 4.

(23 X 1980). Odpowiedzialność za naród i państwo. Referat Ryszarda Reiffa na posiedzeniu Zarządu Stowarzyszenia PAX w dniu 20 X 1980 r. Słowo Powszechne, 331, 3.

(24 XI 1980). Wspólna praca zadecyduje o losie Polski. Przemówienie posła Ryszarda Reiffa (Koło PAX). Słowo Powszechne, 254, 2.

(25 VIII 1980). Prymas Polski wobec potrzeby chwili. Słowo Powszechne, 183, 1.

(25 X 1981). Front niewiarygodnych. Rzeczywistość, 23, 4.

(25 XI 1980). Jesteśmy za ładem i porządkiem. Słowo Powszechne, 255, 1-2.

(26 IX 1980). Rozszerzenie pomocy państwa dla studentów i młodych małżeństw. Słowo Powszechne, 208, 1-2.

(27 VIII 1980). Powaga chwili i zapowiedź zwrotu. Słowo Powszechne, 185, 1.

(27 VIII 1980). Prymas Polski wobec potrzeby chwili. Słowo Powszechne, 185, 5.

(27 X 1980). Współgospodarze. Słowo Powszechne, 233, 1, 4.

(28 IX 1980). Kierunki, 39, 3.

(26 X 1980). Linia działania. Dwa przemówienia R. Reiffa podsumowujące dyskusję na posiedzeniach Zarządu Stow. PAX w dn. 4 i 15 IX br. Kierunki, 43, 2.

(28 X 1981). Poszerzenie ośrodka władzy - jedyną drogą wyjścia z kryzysu. Wystąpienie R. Reiffa na zebraniu aktywu Oddziału Stołecznego Stow. PAX w dniu 27 X 1981 r. Kierunki, 45, 1, 3. 
(28 XI 1980). List Zarządu Stowarzyszenia PAX do członków, kandydatów i sympatyków. Stowo Powszechne, 257, 1.

(28 XI 1980). Posiedzenie Zarządu Stowarzyszenia PAX. Słowo Powszechne, 257, 1-2.

(29 III 1981). Autentyczny samorząd chłopski. Kierunki, 12, 1, 8.

(3 II 1980). Dialog metodą wzbogacania kultury narodowej. Wystąpienie Przewodniczącego Stow. PAX R. Reiffa. Kierunki, 5, 1-2.

(3 XI 1980). Nadzwyczajny zjazd delegatów SDP zakończył obrady. Słowo Powszechne, $238,1-2$.

(30 III 1980). Opinia publiczna. Dyskusja redakcyjna. Kierunki, 13, 1, 3.

(30 IX 1980). Dojrzewanie światopoglądowości. Kierunki, 48, 3.

(30 VIII 1980). Co należy uszanować i wypełnić, aby w Ojczyźnie zapanował spokój. Słowo Prymasa ks. Kard. Stefana Wyszyńskiego na Jasnej Górze. Słowo Powszechne, $186,1-2$.

(30 X 1980). Przemówienie Ryszarda Reiffa. Ład i porządek warunkiem odnowy odnowa warunkiem ładu i porząaku (ze stenogramu Komisji). Słowo Powszechne, $236,1-2$.

(4 X 1981). Konieczna alternatywa. Rzeczywistość, 20, 4.

(5-7 IX 1980). Harmonia Bożo-ludzka w Polsce. Słowo Powszechne, 192, 7.

(6 I 1980). Konieczna jest zawsze metoda wszechstronnego bilansu. Wystąpienie Przewodniczącego Stow. PAX R. Reiffa na ogólnopolskiej naradzie oddziałów miejskich Stow. PAX w dniu 11 XI 1979 r. Kierunki, 1, 1, 3.

(6 IV 1980). Posiedzenie Zarządu Stow. PAX. Referat R. Reiffa. Kierunki, 14, 2.

(6 VII 1980). Jego Eminencja Kardynał Wyszyński przyjął Ryszarda Reiffa. Kierunki, $27,1$.

(6 XI 1980). Łączyć potrzeby społeczne z wymogami racji stanu. Wypowiedź Ryszarda Reiffa podsumowująca obrady COSK Stow. PAX oraz przedstawicieli związanej z PAX-em młodzieży akademickiej w dniu 5 X br. Słowo Powszechne, 241, 2.

(6 XII 1981). Jaką drogą w lepszą przyszłość Polski. Rozmowa z Tadeuszem Grabskim. Rzeczywistość, 29, 3.

(7-9 XI 1980). Cały naród bazą sojuszu polsko-radzieckiego. Słowo Powszechne. 242, s. 1.

(7 I 1979). Bolesław Piasecki nie żyje. Kierunki, 1, 1.

(7 XII 1980). Kierunki, 49, 1-2.

(7 XII 1981). Chrześcijaństwo a socjalizm. Dyskusja z okazji 35-lecia Stow. PAX. Kierunki, 49, 6-7.

(8 IX 1980). Przebieg poselskiej debaty. Słowo Powszechne, 193, 4.

(8 IX 1980). Sytuacja w kraju tematem posiedzenia Zarządu Stowarzyszenia PAX. Słowo Powszechne, 193, 1.

(8 VII 1979). Posiedzenie Zarządu Stowarzyszenia PAX. Kierunki, $27,2$.

(8 XI 1981). Front porozumienia, ale jaki?. Rzeczywistość, 25, 4.

(9 IX 1980). Polska to całość. Przemówienie sejmowe posła Ryszarda Reiffa (Koło PAX). Słowo Powszechne, 194, 4.

(9 XI 1980). Kierunki, 45, 1, 3. 
(9 XII 1979). Posiedzenie Zarządu PAX. Kierunki, 49, 2.

(27 VIII 1980). Uroczystości Matki Bożej Częstochowskiej. List Episkopatu Polski. Słowo Powszechne, 185, 5.

Bocheński, A. (1981). Rozmyślania o reformie. Kierunki, 36, 1, 3.

Czajkowski, Z. (1980). W duchu prawdy światopoglądowej. Słowo Powszechne, 222, 1.

Czajkowski, Z. (1980). 1948-1980. Słowo Powszechne, 254, 1.

Czajkowski, Z. (1981). Front Jedności Narodu. Słowo Powszechne, 17, 3-4.

Giżyński, Sz. (1980). Tradycje polskiej myśli socjalistycznej. Kierunki, 24, 5.

Górecki, J. (1981). Socjalizm całego narodu, czy antysocjalizm?. Rzeczywistość, 25, 4

Górecki, J. (1981). Warunki realizacji. Rzeczywistość, 29, 1, 4.

Idea porozumienia: front, rada, czy komitet? Zapis magnetofonowy wystąpienia Ryszarda Reiffa z dn. 18 XI 1981 r. Kierunki, 49, 1-2.

Jaworska, M., Machnacki, M. (1980). Stypendia: zasady i tryb przydzielania. Słowo Powszechne, 207, 5.

Kaczorowski, A.W., Mach J., Machnacki, M. (1981). Rejestracja, czyli prawdziwe święto chłopów. Kierunki, 21, 11.

Komender, Z. (1980). Ranga społecznych celów. Słowo Powszechne, 188, 1-2.

Komender, Z. (1980). Wyzwolić ludzkie możliwości. Słowo Powszechne, 165, 3.

Komender, Z. (1980). Potrzeba ładu moralnego. Kierunki, 40, 1-2.

Kot, A. (1981). Strajk łódzkich studentów zakończony. Słowo Powszechne, 37, 1-2.

Kot, A. (1980). Czy łódka zmienia się w jacht. Słowo, 233, 3.

Król, J. (1981). W służbie wartości. Kierunki, 1, 3.

L.F. (1981). Słowa i ton. Trybuna Ludu, 249, 2.

Lewandowski, W. (1981). Nie powtarzać starych błędów. Słowo Powszechne, 36, 3.

Łączyć potrzeby społeczne z wymogami racji stanu. Wypowiedź Ryszarda Reiffa podsumowująca obrady COSK Stow. PAX oraz przedstawicieli związanej z PAX-em młodzieży akademickiej w dniu $5 \mathrm{X}$ br. Słowo Powszechne, 241, 2.

Machnacki, M., Jabłońska M. (1980). Pomoc uczelni dla studentów. Słowo Powszechne, 231,4 .

Majkut, E. (1980). A może izby rolnicze. Słowo Powszechne, 246, 3.

Michta, N. ( 1981). Wokół idei Frontu Porozumienia Narodowego. Rzeczywistość, $29,5$. mos. (1980). Zapomniany samorząd. Słowo Powszechne, 202, 1.

mos. (1980). Kompetencje i odpowiedzialność. Słowo Powszechne, 190, 1.

mos. (1980). Uznanie słusznych spraw. Słowo Powszechne, 92, 1.

Na nowej drodze. Dyskusja na posiedzeniu Stow. PAX w dniu 4 IX 1980 r. Kierunki, $43,1,5-7$.

Niegodzisz, G. (1980). Ruch studencki: znaleźć sobie miejsce. Słowo Powszechne, 250, 3.

Olszewski, W., Dobraczyński J. (1980). W imię ogólnonarodowej solidarności. List do redakcji. Słowo Powszechne, 188, s 2.

Piasecki, B. (1956). Instynkt państwowy. Kierunki, 23, 1-2.

Piasecki, B. (1945). Zagadnienia istotne. Dziś i Jutro, 1-3.

Piecha, K., Stelmaszczyk L. (1980). Samorząd przez wielu rządzony. Słowo Powszechne, $243,3$. 
Radajewski, A. (1981). Świeckość państwa socjalistycznego. Kierunki, 27, 1, 3.

Radajewski, A. (1980). Rozwiązanie. Kierunki, 36, 1.

Reiff, R. (1981). Poszerzenie ośrodka władzy jedyną drogą wyjścia z kryzysu. Kierunki, $45,1,3$.

Reiff, R. (1979). Doskonalić rzeczywistość i służyć człowiekowi - oto platforma dialogu i współdziałania. Kierunki, nr 26, 3.

Reiff, R. (1981). Chodzi o solidarność całego narodu. Wywiad z R. Reiffem. Kierunki, $44,1-3$.

Reiff, R. (1981). Czy zdołamy zapobiec katastrofie i wyjść z kryzysu?. Kierunki, 50, 1-2.

Reiff, R. (1980). Demokracja polska. Słowo Powszechne, 248, 3-5.

Reiff, R. (1980). Demokracja polska. Kierunki, 47, 3, 6-7.

Reiff, R. (1980). Tożsamość narodu podstawą jedności wszystkich Polaków. Kierunki, $29,1,3$.

Reiff, R. (2006). Archiwum Stowarzyszenia PAX. Publicystyka polityczna. T. 1: Refleksje $z$ pogranicza historii, ideologii i polityki Stowarzyszenia PAX. Warszawa: wyd. Comandor.

Reiff, R. (1980). Patriotyzm jest jeden. Słowo Powszechne, 159, 1.

Reiff, R. (1979). Kontynuacja i rozwój. Kierunki, 3, 2.

Reiff, R. (1981). Potrzeba wyobraźni i realizmu. Kierunki, 47,1-2.

Reiff, R. (1980). Czas próby. Słowo Powszechne, 232, 3-4.

Reiff, R. (1981). Wielka koalicja. Kierunki, 43, 1-3.

Reiff, R. (1981). Strategia polskiej odnowy. Kierunki, 36, 2.

Reiff, R. (1980). Siłą socjalizmu - więź z narodem. Słowo Powszechne, 193, 3-4.

Reiff, R. W stronę państwa ogólnonarodowego. Kierunki, 40, 2.

Reiff, R. (1981). Linia odnowy i odpowiedzialności. Słowo Powszechne, 117, 5-6.

Rowicki, J. (1980). Siły i zamiary. Słowo Powszechne, 213, 3.

Rowicki, J. (1980). Szkoła wyższa a samorządność, Słowo Powszechne, 207, 1.

Wlazło, S. (1981). Sedno problemu. Kierunki, 16, 3.

sas. (1980). Studenci. Słowo Powszechne, 212, 1.

Siwek, S. (1980). Autentyczność ruchu studenckiego. Kierunki, 43, 9.

Skrzypkowski, Z. (1980). Robotnicy są niecierpliwi, Słowo Powszechne, 239, 3.

Stefanowicz, J. (1980). Witamy porozumienie. Słowo Powszechne, 189, 1.

Stefanowicz, J. (1980). Samorządność i państwo. Słowo Powszechne, 221, 3

Stefanowicz, J. (1980). W słusznym kierunku. Słowo Powszechne, 181, 1.

Stefanowicz, J. (1980). PAX a kultura narodowa. Słowo Powszechne.

Stefanowicz, J. (1980). Refleksja po Plenum. Słowo Powszechne, 218, 1.

Stelmaszczyk, L.. (1980). Biurokratyzm, marazm, brak autentyzmu. Przyczyny zaniku samorządności wiejskiej. Słowo Powszechne, 229, 3.

Szwechowicz W. (1980). O socjalistycznym zaangażowaniu PAX-u. Kierunki, 24, 5.

Szwechowicz, W. (1981). Bez ideologii. Kierunki, 18, 9.

Szwechowicz, W. (1981). System a układ partnerski. Kierunki, 22, 8.

Szwechowicz, W. (1981). Socjalizm demokratyczny. Kierunki, 14, 8.

Ślaski, J. (1980). W naszych rękach. Słowo Powszechne, 246, 1. 
Ślaski, J. (1980). Rolnictwa sprawy najważniejsze. Słowo Powszechne, 252, 1.

Ślaski, J. (1981). Ustawa - początek drogi. Słowo Powszechne, 84, 1.

Ślaski, J. (1980). Ciężar wspólnej odpowiedzialności. Słowo Powszechne, 237, 1.

Ślaski, J. (1980). Po zjeździe SDP. Słowo Powszechne, 239, 1.

Ślaski, J. Rolnictwo: co, kiedy, gdzie?. Słowo Powszechne, 197, 1.

Ślaski, J. (1981). Tym, którzy mówią. Słowo Powszechne, 244, 2.

Wagner, J. (1981). Zgodnie z tożsamością. Kierunki, 27, 3, 6.

Wandowski, H. (1981). Socjalizm wydrążony. Rzeczywistość, 27, 3, 10.

Wołkowski, J. (1981). Alienacja światopoglądowa. Kierunki, 28, 3.

Wójcik, J. (1979). Nasza postawa. Kierunki, 47, 1, 7.

Wójcik, J. (1980). Twórca współczesnego katolickiego ruchu społecznego. Kierunki, 1, $1,6$.

Wyszyński, S. (1980). Odpowiedzialność - obowiązki - prawa w życiu narodu. Kierunki, $36,1,3$.

Znamieniecki, P. (1981). Panorama polska. Rzeczywistość, 26, 1, 4.

Znamieniecki, P. (1981). Decydujący moment. Rzeczywistość, 20, 1, 4.

\section{Opracowania:}

(10-17 VI 2007). Co Piasecki proponował PKWN?. Myśl Polska.

(1980). Doświadczenie i przyszłość. Ocena sytuacji w Polsce i prognoza rozwoju wydarzeń na dzień 10 lipca 1981 roku, Warszawa: na prawach maszynopisu.

(21 I 1979). Ryszard Reiff (biogram). Kierunki, 3, 2.

Bankowicz, B. (2009). Stowarzyszenie PAX: między rzeczywistością socjalizmu realnego a utopią socjalizmu wieloświatopoglądowego. W: A. Citkowska-Kimla, M. Kiwior-Filo, B. Szlachta (red.), Doktryny, historia, władza: księga dedykowana Profesorowi Wiesławowi Kozubowi-Ciembroniczowi z okazji czterdziestolecia pracy naukowej (37-48). Kraków: wyd. UJ.

Bankowicz, B. (1989). Wieloświatopoglądowość socjalizmu w ujęciu Bolesława Piaseckiego. Zeszyty Naukowe UJ. Prace z Nauk Politycznych, 34, 7-19.

Bankowicz B. (1996). W labiryncie wieloświatopoglądowości: Stowarzyszenie PAX między marzeniem a rzeczywistością. W: B. Bankowicz, A. Dudek (red.), Ze studiów nad dziejami Kościoła i katolicyzmu w PRL (53-71). Kraków: wyd. PiT.

Blit, L. (1965). The Eastern Pretender. Bolesław Piasecki his life and times. London.

Bromke, A. (1961). From „Falanga” to PAX. London: wyd. Surwey.

Burdeński, Z. (1988). Kierunki rozwoju działalności PAX w latach 1945-1985. Warszawa [maszynopis w: AIPN BU 01521/2190].

Dudek, A., Pytel, G. (1990). Bolesław Piasecki. Próba biografii politycznej. Londyn: wyd. Polska Fundacja Kulturalna.

Dudek, A. (2013). Program Stowarzyszenia PAX. Realizm, koniunkturalizm czy utopia?. Politeja, 3, 69-78.

Dudek, A. (1996). Stowarzyszenie PAX w systemie politycznym Polski Ludowej w świetle dokumentów. W: B. Bankowicz, A. Dudek (red.), Ze studiów nad dziejami Kościoła i katolicyzmu w PRL. Kraków: wyd. PiT. 
Dworaczek, K. (2014). Stowarzyszenie PAX wobec „Solidarności” i Niezależnego Zrzeszenia Studentów. W: R. Ptaszyński, T. Sikorski (red.), Sensus catholicus. Katolicy świeccy w Polsce Ludowej. Postawy - aktywność - myśl. Studia i szkice. Toruń: wyd. Adam Marszałek.

Engelgard, J. (2008). Wielka gra Bolesława Piaseckiego. Warszawa: wyd. „Myśli Polskiej”. Engelgard, J. (2015). Bolesław Piasecki 1939-1956, Warszawa: wyd. „Myśl Polska”.

Engelgard, J. (2015). Wielka gra Bolesława Piaseckiego. Warszawa: wyd. „Myśl Polska”.

Friszke, A. (1994). Opozycja polityczna w PRL 1945-1980. Londyn: wyd. Aneks.

Friszke, A. (2015). Między wojną a więzieniem 1945-1953. Młoda inteligencja katolicka. Warszawa: wyd. „Więź”, ISP PAN.

Friszke, A., Paczkowski A. (12 IV 2007). Chcę współpracować. Bolesława Piaseckiego memoriały więzienne. Tygodnik Powszechny.

Garlicki, A. (1993). Z tajnych archiwów. Warszawa: wyd. Czytelnik.

Garlicki, A. (1998). Zeznania Bolesława Piaseckiego. Zeszyty Historyczne, 126, 82-112.

Gasztold-Sen, P. (2012). Koncesjonowany nacjonalizm. Zjednoczenie Patriotyczne „Grunwald” 1980-1990. Warszawa: wyd. IPN.

Gontarczyk, P. (2006). „Bliźni” - agent „Albinów”. Gazeta Polska, 37, 14-15.

Gontarczyk, P. (2006). Druga twarz kapitana Jacka. Gazeta Polska, 34, 22-23.

Huk, J. (1984). Stowarzyszenie PAX [maszynopis w: AIPN BU 01521/2092].

Jaszczuk, A. (2002). Ewolucja ideowa Bolesława Piaseckiego 1932-1956. Warszawa: wyd. DiG.

Kazimierski, J. (2013). Katowickie Forum Partyjne. Pamięć i Sprawiedliwość, 2, 209-232. Kozioł, R. (2001). Konserwatorium „Doświadczenie i Przyszłość” - problem opozycyjności. W: K. Łabędź, M. Mikołajczyk (red.), Opozycja w systemach demokratycznych i niedemokratycznych. Kraków: wyd. Katedra Politologii Instytutu Nauk Społecznych AP im. KEN.

Kozioł, R. (2002) Konwersatorium „Doświadczenie i Przyszłość” wobec zagadnień samorządności terytorialnej. Annales Academiae Paedagogicae Cracoviensis. Studia Politologica, 1, 155-176.

Kuciński, J. (1988). Ryszarda Reiffa koncepcja wieloświatopoglądowego państwa ogólnonarodowego i „Wielkiej Koalicji” (1980-1981). Studia Społeczno-Polityczne Akademii Nauk Społecznych przy KC PZPR. Warszawa, 1, 103-109.

Kunicki, M.S. (2002), The Polish Crusader - the Life and Politics of Bolesław Piasecki (1915-1979), PhD diss. (Stanford Uniwersity) [niepublikowana dysertacja doktorska].

Marcinkiewicz, M. (2010). Nieudana reforma Stowarzyszenia PAX i próby utworzenia Konfederacji Polski Niepodległej w Gorzowie Wielkopolskim. Dzieje Najnowsze, 1, 167-194.

Micewski, A. (1978), Wspótrządzić czy nie kłamać? PAX i Znak w Polsce 1945-1976. Paryż: wyd. Libella.

Mysłek, W. (1982). Kryptochadecja (2). Posierpniowe zakusy PAX-u. Argumenty, 25.

Niedzielko, R., Noszczak, B. (2006). Bolesława Piaseckiego przepustka do wolności. Tygodnik Powszechny, 5. 
Paczkowski, A. (2009). Trzy twarze Józefa Światły. Przyczynek do historii komunizmu w Polsce. Warszawa: wyd. Prószyńskie Media.

Pietrow, N. (2013). Stalinowski kat Polski Iwan Sierow, Warszawa: wyd. Demart.

Pilecki, M. (1986). Doktryny programowe PAX między sierpniem 1980 a grudniem 1981 roku. Warszawa [maszynopis w: AIPN BU 1708/2662).

Rymar D.A. (2010). Nieznane fakty z życia Andrzeja Gordona (1945-1992). Przyczynek do gorzowskiej biografistyki. Nadwarciański Rocznik Historyczno-Archiwalny, 17, 427-435.

Sikorski, T. (2009). Od „wewnętrznej niepodległości” do „narodowego kompromisu”. Koncepcja rewindykacji PRL w publicystyce „Głosu” (1977-1983). W: T. Sikorski, H. Walczak, A. Wątor (red.), W kręgu idei, polityki i wojska. Studia ofiarowane Profesorowi Januszowi Farysiowi w siedemdziesiątą rocznicę urodzin (201-224). Szczecin: wyd. Uniwersytetu Szczecińskiego.

Sikorski, T. (2010). Realizm środowiska „Głosu” i Grupy Publicystów Politycznych w konfrontacji z rzecznikami idealizmu politycznego w drugiej połowie lat 80-tych XX wieku. W: G. Radomski, W. Wojdyło, M. Zamojska, Drogi do niepodległości. Szanse, kontrowersje, problemy (91-101). Toruń: wyd. Adam Marszałek.

Sikorski, T. (2016). Prasa centralna Stowarzyszenia PAX wobec „odwilży” $i$ „polskiego października" 1956 roku, 27-44.

Urbankowski, B. (2006). Wallenrod czasów marnych i niebezpiecznych. Gazeta Polska. Urbański, J. (1979). Kategoria „pluralizmu światopoglądowego” w ujęciu Stowarzyszenia PAX. Zeszyty Naukowe WAP, 101.

Waligóra, G. (2004). Romuald Szeremietiew - opozycjonista z PAX. Pamięć i Sprawiedliwość, 3/2, 329-339.

Wójcik, J. (1978). Droga krystalizacji potrójnego zaangażowania ruchu społeczno-postępowego (1945-48). W: Materiały do historii ruchu społecznie-postępowego PAX, t. II (8-17). Warszawa: na prawach maszynopisu. 